
$\$$ Research Square
Preprints are preliminary reports that have not undergone peer review.
They should not be considered conclusive, used to inform clinical practice, or referenced by the media as validated information.

\title{
Shallow seismic characteristics and distribution of gas in lacustrine sediments at Lake Erçek, Eastern Anatolia, Turkey, from high-resolution seismic data
}

Mustafa Toker ( $\square$ tokermu@gmail.com)

Yüzüncü Yıl Üniversitesi: Van Yuzuncu Yil Universitesi https://orcid.org/0000-0001-9981-6605

Hüseyin Tur

Istanbul University-Cerrahpasa: Istanbul Universitesi-Cerrahpasa

\section{Research Article}

Keywords: Lake Erçek, Seismic chimneys, Enhanced reflections, Pockmarks, Acoustic gas masking, Gascharged sediments

Posted Date: May 4th, 2021

DOI: https://doi.org/10.21203/rs.3.rs-488174/v1

License: (c) (i) This work is licensed under a Creative Commons Attribution 4.0 International License.

Read Full License 


\section{Abstract}

The high-resolution analysis of single-channel, seismic reflection data from Lake Erçek (Eastern Anatolia) revealed a wide range of shallow gas anomalies consisting of enhanced reflections, seismic chimneys, acoustic blanking/acoustic turbidity, strong reflectors, and pockmarks, including both surface and buried pockmarks. The enhanced reflections are represented by the higher-amplitude reflection patterns resulting from high acoustic impedance variations. They are mostly clustered in the NW-corner of the lake. Seismic chimneys are represented by vertical and thinned columnar disturbances of amplitude blanking and mostly occurred in deep basinal and faulted sections in the West and East of the lake. Some seismic chimneys, occurring together with pockmarks, represent vertical vent activations. Acoustic gas-masking was represented by chaotic and diffuse seismic reflection patterns, including acoustic blanking and acoustic turbidity. As diffuse acoustic turbidity indicates gas-charged sediments, columnar disturbances showing acoustic blanking indicate degassing of the sediments. These features extend from SE to NW, coinciding with the deep basin morphology of the lake. A very local strong reflector was identified in the western section of the lake, simulating the lake floor. This reflector is due to extended enhanced reflections, suggesting shallow free gas. Pockmarks observed in the lake are structurally classified into the two distinct types; surface (active) pockmarks found in the SE-part of the lake and buried (passive) pockmarks found in the NW. The former enlarge through deeper gas reservoir feedback, as the layering is impermeable, while the latter have resulted from a cessation of the reservoir feedback mechanism and/or permeable layering. In the lake, shallow gas distribution is controlled by faults, that provide the faultingdriven depositional control and earthquakes, that provide the seismicity-driven overpressure control. The shallow gas is then both vertically and horizontally distributed and, finally, distribution is shaped by asymmetric depositional and stratigraphic factors. This study of Lake Erçek presents complementary information about a possible origin of observed shallow gas and is important in identifying the pockmark types to be targeted for oil/gas exploration and valuable geochemical proxies.

\section{Introduction}

Methane gas emission, migration and concentration, one of the most potent threats to the Earth's atmosphere (Jaśniewicz et al., 2019), is a strong mechanism for the production of greenhouse gases (Judd et al. 2002). The global warming potential of methane is more than 20 times higher than $\mathrm{CO}_{2}$ (Hovland and Judd 1988, Hovland et al. 1993, Judd et al. 2002, Lowe and Walker 1997; Vardar and Alpar, 2016). These mechanisms include methane fluxes in the seabed and into the air due to the exploitation of fossil fuels leading to potential instability in gas reserves in shelves and slopes (Çifçi et al., 2003) and free gas accumulation in sediment pore spaces (e.g., Prior and Coleman 1984; Hovland and Judd 1988; Yun et al. 1999; Çifçi et al., 2003). Worldwide gas bearing sediments (e.g., Emeis et al. 2004, Laier and Jensen 2007, Mazumdar et al. 2009, Chun et al. 2012) occur typically in shallow water environments with a depth of less than $50 \mathrm{~m}$ (Fleischer et al. 2001; Vardar and Alpar, 2016). If methane concentrations are high enough to exceed methane solubility, then free gas occurs and permits the formation of gas bubbles (Schubel 1974, Abegg and Anderson 1997, Whiticar 2002; Vardar and Alpar, 2016). Previous studies 
report that shallow water gas emission contributes as much as $20 \%$ of total methane emission to the air (Hovland et al. 1993; Fleischer et al. 2001; Jaśniewicz et al., 2019).

The presence of gas in marine and lacustrine settings was identified about sixty years ago (Koyama, 1953; Emery and Hoggan 1958; Lodolo et al., 2012), while gas-induced anomalous structures (pockmarks) were first discovered more recently in the continental shelf of Nova Scotia, Canada (King and MacLean 1970; Çifçi et al., 2003). Many more subsequent geophysical studies have focused on the seismo-acoustic behaviors of gas-charged sediments (Garcia-Gil et al. 2002; Missiaen et al. 2002; Bertin and Chaumillon, 2005; Gwang et al. 2005; Lodolo et al., 2012). Since, it has been recognized that hydrocarbon-bearing deposits constitutes up to $30 \%$ of continental shelves (e.g., St. John 1984), which have high potential for gas accumulation (Hovland et al. 1993; Jaśniewicz et al., 2019). This allows seismo-acoustic detection to be applied (Schüler 1952; Anderson and Hampton 1980; Abegg and Anderson 1977) due to the distinct seismo-acoustic properties of gas-charged sediments (Jaśniewicz et al., 2019). In addition, seismic indicators of shallow gas deposits have been a major target for exploration geophysicists and a valuable source for the petroleum industry (Schroot and Schuttenhelm, 2003; Judd and Curzi, 2002). They have been reported not only in marine settings (Hovland, 1981a, b; Hovland and Judd, 1988; Judd and Hovland, 1992; Hovland, 1992; Garcia-Gil et al., 2002; Gay et al., 2007; Naudts et al., 2009), but also in orogenic lacustrine basins (Toker and Şengör, 2011; Toker et al., 2017a; Çukur et al., 2014; Çukur et al., 2013a, b; Toker and Tur, 2018). Unstable lacustrine basins in tectonically highly active orogenic settings (see unstable tectonic lakes by Hage et al., 2017; Wagner et al., 2012; Leroy et al., 2010; Jakobsson et al., 2014; Van Daele et al., 2015; Wallner, 2008; Çukur et al., 2013a, b; Solovyeva et al., 2016; Shiki et al., 2000 and many others from bibliographic research atlas of world lakes, compiled by Sammartini et al., 2020) have challenged geoscientists for decades and become a leading topic over the past twenty years (e.g., International Continental Drilling Program, ICDP-PaleoVan project by Litt et al., $2009,2011,2014)$.

In recent years, the understanding of gas/fluid-related depositional settings associated with tectonics and sedimentation has been greatly enhanced by studies of highland Lakes Van and Erçek basins in the East Anatolian Orogen (E-Anatolia) (Fig. 1) by analysis of multi- and single-channel seismic reflection and Geochirp data (Çukur et al., 2014; Çukur et al., 2013a, b; Toker et al., 2017a; Tomonaga et al., 2017; Toker and Tur, 2018). The understanding of Lake Van and Lake Erçek has been advanced by crustal tomographic studies (e.g., tectono-magmatic genesis reported by Toker and Şahin, 2019) and basin-wide investigations from Lake Van (e.g., Wick et al., 2003; Stockhecke et al., 2014a, b; Litt et al., 2009, 2011, 2014; Vigliotti et al., 2014; Kwiecien et al., 2014; Çukur et al., 2014; Randlett et al., 2017). An interesting aspect of Lake Van is the presence of considerable accumulations of gas and fluids (mantle-sourced fluids and He emissions) within the sediments (Kipfer et al., 1994; Kaden et al., 2010; Tomonaga et al., 2011; Çukur et al., 2013b) where active faults and fractures provide conduits for gas migration and also intrusive-extrusive magma propagation (Toker et al., 2017a). However, a similar scenario has not been proposed for the adjacent Lake Erçek trough (Figs. 1a, b), which has undergone a complete process of Quaternary deformation that includes normal faulting, strong extensional tectonism, initial half-graben geometry, asymmetric subsidence, intense and continuous basement uplifting, slow depositional filling, 
and thin sedimentation (see Toker and Tur, 2018 for details). However, the Lake Erçek trough is much younger than Lake Van basin (Toker et al., 2017a). Unfortunately, Lake Erçek has been little studied, scientifically isolated from international research programs for Lake Van and considered as a shalloweryounger lake of little interest. Given that the shallow gas and/or fluids in the Lake Erçek Basin have not been investigated yet, a study of shallow gas in this location can provide additional advantages that make a more complete seismic structural study of Lake Erçek basin (Toker and Tur, 2018) vital to improving our knowledge of shallow gas, gas migration and related deformations, and even the origin of fluids (if available) into orogenic lakes. In this respect, understanding the distributional pattern of the gas and related deformations is crucial for geohazard mitigation in the highland lacustrine settings of EAnatolia.

In shallow water environments, such as lakes, rivers, estuary, and continental shelves, that are often characterized by rapidly accumulating, organic-rich, and fine-grained sediments (Visnovitz et al., 2015), seismic reflection profiling is considered to be useful for the distributional pattern of shallow gas. Seismo-acoustic profiling methods are non-invasive, relatively low cost and are based on continuous measurement over the area of interest, which provides a fast and detailed image of shallow gas occurrences and their spatial distribution (e.g., Orange et al. 2005; Visnovitz et al., 2015; Jaśniewicz et al., 2019). This is mainly due to the very distinctive acoustic properties of shallow gas in comparison with the surrounding water and sediments (Anderson and Hampton 1980; Wilkens and Richardson 1998; Jaśniewicz et al., 2019) and also, the strong attenuation of high-frequency signals that allows the detection of very low amounts of free gas in sediments (e.g., Duarte et al. 2007; Visnovitz et al., 2015). The signal attenuation phenomenon is, in fact, an "acoustic problem" caused by shallow free gas as it has been recognized as impeding imaging of the depositional structure (Tóth et al., 2014). Measurements made using high frequency $(>1 \mathrm{kHz})$ acoustic profiling indicate "chaotic reflections" as acoustic turbidity and "absence of reflections" as acoustic blanking in muddy deposits (e.g. Garcia-Gil et al., 2002; Mathys et al., 2005; Laier and Jensen, 2007; Tóth et al., 2014). The high frequency components of seismic waves are attenuated in the gas-charged depositional layers due to scattering caused by gas bubbles. The scattering effect obscures the depth of free gas and also the seismic expression of the deposits below, but only the top of the shallow gas accumulation, the gas front, is observable (Judd and Hovland, 2007; Tóth et al., 2014). Higher frequency seismic surveying (e.g., $10 \mathrm{kHz}$ seismic sources), with a higher signal to noise ratio and higher vertical resolution (as good as decimeters) for gas provides small footprints of the seismic signal with a higher horizontal resolution, allowing a complete characterization of shallow gas.

Shallow gas appears in seismic reflection profiles mainly as acoustic turbidity and acoustic blanking (Judd and Hovland 1992; Mathys et al. 2005; Visnovitz et al., 2015). It also causes seismic chimneys, enhanced reflections (e.g., Judd and Hovland 1992), reversed polarity reflections (e.g., Garcia-Gil et al., 2002), reverberation or ringing (e.g., Davy 1992; Baltzer et al. 2005), and velocity pull down effects (e.g., Anderson and Bryant 1990; Mathys et al. 2005; Visnovitz et al., 2015). In addition, migration and expulsion of shallow gas can create distinct bathymetric depressions known as "pockmarks". Pockmarks are generally related to gas and/or fluid discharge in near-surface sediments (Hovland and Judd 1988; 
Çifçi et al., 2003). They are typically circular or elongated hollows in shape, varying from a few meters to a few tens of meters in diameter with depths ranging from $<1 \mathrm{~m}$ to tens of meters (Hovland and Judd 1988) although larger pockmarks have been reported up to several hundreds of meters in width and 200 $m$ in depth (e.g., Solheim and Elverhoi 1993; Cole et al. 2000). They are widespread, from coastal, shallow water areas to deep water settings (e.g., Belfast Bay in Kelley et al. 1994, the Norwegian Trench in Hovland 1981, the Bering Sea in Nelson et al. 1979, the Gulf of Cadiz in Baraza and Ercilla 1996, the continental slope of California in Yun et al. 1999, and in several lake settings in Pickrill, 1993).

To the best of our knowledge, the current research represents the first high-resolution seismic survey in Lake Erçek. It also describes and maps shallow gas-induced seismic anomalies using single-channel seismic reflection profiles collected from Lake Erçek (Fig. 2a) and presents a more detailed and broader view of methane presence in the lake deposits. This study links observed gas leakage indicators, their relative abundance and distribution with the possible deep feeding systems and/or the underlying generic processes and associated structural elements (e.g., faults-fractures) as migration pathways in the study area. The new results reported in the current study provide the additional basis for a refined understanding of the tectonic and sedimentary structure of the Lake Erçek basin. Hence, the current study complements not only previous studies on tectonics and sedimentation in Lakes Van (e.g., ICDP by Litt et al., 2009, 2011, 2014; Çukur et al., 2014; Çukur et al., 2013a, b; Toker et al., 2017a) and Erçek basins (e.g., Toker and Tur, 2018), but also provides a comprehensive view of the methane gas movement and distribution system of the lake. We believe that this study will be of great referential value for bibliographic research of worldwide unstable tectonic lakes (e.g., Sammartini et al., 2020). In addition it will add to the understanding of seismic surveying of gaseous depositional resources of unstable tectonic lakes (e.g., the Lake Baikal rift system in Solovyeva et al., 2016), and also inform hydrocarbon exploration studies in the Lake Erçek basin, where easily accessible and evidence of significant, extensive shallow gas deposits may be an important energy resource.

\section{Seismo-acoustic Behavior Of Shallow Gas-charged Sediments}

The sediment/gas-charged sediment interface has a strong acoustic impedance contrast (P-wave velocity and density) that generates a characteristic reflector (an abrupt decrease in P-wave velocity and/or in bulk density) attributed to the presence of the gas. Hence, the interface presents reversed polarity with respect to the lake floor reflector, which is characterized by normal polarization due to the positive water/sediment impedance contrast (Lodolo et al., 2012). High acoustic impedance contrast, and also elastic contrast in relation to the surrounding medium non-gaseous sediments or water column, determines high acoustic energy scattering properties (Jaśniewicz et al., 2019). Based on high attenuation of acoustic energy and/or by reduction of acoustic signal propagation speed (Anderson and Hampton 1980; Wilkens and Richardson 1998; Jaśniewicz et al., 2019), the gas-charged deposits and/or bubbles in the water column can be simply and effectively detected.

Seismo-acoustic properties of shallow gas occurrence are dependent on the concentration of gas, its distributional pattern, and the applied acoustic method. It is understood that methane exists in two main 
forms in marine deposits: dissolved or gaseous (bubbles) (Jaśniewicz et al., 2019). In deposits, gas may occur as: type 1 - interstitial bubbles between adjacent sediment particles; type 2 - reservoir bubbles between many sediment particles; and type 3 - bubbles which displace surrounding sediments (Jaśniewicz et al., 2019). Most gas bubbles have been reported to be of the type 2 and type 3 (based on sediment samples collected by Jackson and Richardson 2007; Anderson et al. 1998; Best et al. 2004, Boudreau et al. 2005; Jaśniewicz et al., 2019). Free gas bubbles have a typical resonance frequency and can strongly vibrate and scatter energy when stimulated at this frequency (e.g., strong attenuation due to scattering and/or reflection in Lodolo et al., 2012; Tóth et al., 2014). The resonance frequency depends on the dynamic shear modulus, the density of the sediments, the hydrostatic pressure, the thermal properties of gases and bubble radius (conducted on gas-charged sediments by Anderson and Hampton 1980; Wilkens and Richardson 1998; Best et al., 2004; Lodolo et al., 2012). This case corresponds to the wellknown "acoustic turbidity zone", that is, the masking of sedimentary horizons by absorption and scattering of seismic energy due to free gas bubbles (Lodolo et al., 2012), as extensively described by Hovland and Judd (1988) and Judd and Hovland (2007). Deducible information about free gas from frequency-dependent seismo-acoustic signatures and images of shallow free gas is also reported in detail and widely discussed by Tóth et al., (2014).

\section{Structural Setting}

Lake Erçek is an endoreic basin with water depths ranging from $5 \mathrm{~m}$ to $40 \mathrm{~m}$, located to the $\mathrm{E}$ of Lake Van endoreic basin in the Van region of E-Anatolia (Fig. 1). Lake Erçek is a tectonically formed soda lake, similar to the nearby Lake Van (see Toker and Tur, 2018 for details and references therein). Both lakes are considered to have similar tectonic and magmatic features and hence, thermal characteristics, as detailed and discussed elsewhere (Toker and Şahin, 2019 and references therein).

Lake Erçek basin consists of three distinct morpho-physiographic provinces; lacustrine shelf (Ls) with 0$15 \mathrm{~m}$ water depth, sublacustrine shelf (SLs) with 15-25 m water depth, and deep basin (DB), beneath more than $25 \mathrm{~m}$ water depth (Toker and Tur, 2018). The lake was downlifted as a result of N-S compressional and W-E extensional processes during the early Pliocene. Its deep basinal structure began to develop because of N-S striking faults in the Upper Pleistocene (Toker and Tur, 2018). N-S compressional stress resulted in W-E striking, vertical reverse faults in N-and S-marginal sections and N-S striking extensional normal faults in W-and E-marginal sections of the lake. As a result, an asymmetrically subsiding, half-graben depositional geometry of this lake was formed, while faultcontrolled marginal sections were uplifted and eroded (Toker and Tur, 2018). There is a gently sloped and widely developed delta platform across the E-margin of the lake, while a fault-controlled, narrow and steep slope forms its W-margin. Vertical reverse faulting-controlled basement highs and their erosive surfaces are also evident across the W-parts of the $\mathrm{N}$ - and S-margins.

In the lake, due to N-S compression, W-E extensional tectonism strongly affected the overall geometry of the sedimentary infill and produced depositional asymmetry. Depositional sections (not more than $~ 80$ m-100 $\mathrm{m}$ thick) are structurally deformed by small scale folds along $\mathrm{N}$ - and S-margins and faults- 
fractures along W-and E-margins. Particularly, in some locations, unlithified, $\sim 15 \mathrm{~m}-20 \mathrm{~m}$ thick piles of soft sedimentary bedding are disturbed and local sediment packages are disrupted by gas and/or fluids. Unfortunately, no detailed information about lithology of the sediments and the composition of the gas is available. For that, drilled sediment information would be required for detailed analyses. Further description and discussion on the tectonic control and the structural deformation of Lake Erçek, together with Lake Van can be found elsewhere (Toker et al., 2017a, b; Toker and Tur, 2018; Toker and Şahin, 2019; Toker, 2021).

\section{Datasets And Methods}

The single-channel seismic reflection datasets used in this study include over $100 \mathrm{~km}$ of high-resolution seismic reflection profiles (Fig. 2a) collected in 2015. A three-component seismic system was used consisting of a single-channel hydrophone streamer with 8 units (5 m in length), a Geo-Boomer 300-500 seismic system and a recording unit. The Geo-Boomer 300-500 (by Geo-Resources) was operated with the Geo-Spark 1000 pulsed high-voltage (HV) power supply. The Geo-Boomer has no sampling frequency. It is the signal of the Geo-Boomer, as detected by the streamer that is sampled by the recording unit. The frequency is $10 \mathrm{kHz}$ with 400 ms penetration depth (max) below bottom, 150 ms water depth (max), and $10 \mathrm{~cm}-20 \mathrm{~cm}$ transducer depth range (below surface). A single acoustic pulse trace of $0.25-0.50 \mathrm{~ms}$ results in a lateral resolution of $0.5 \mathrm{~m}$ and a vertical resolution of $0.15 \mathrm{~m}$. For processing, interpretation and visualization of the seismic data, the acquisition software, The GeoSuite All Works ${ }^{\circledR}$, was used which contains all essential functions for online processing, and it was applied to all the single-channel seismic reflection profiles. Navigation was performed by EGNOS (L1 and L2 spectra) of Pentax 888 3G GNNS (GPS + GLONASS) system fixed on the research vessel and processed by GeoSuite Acquisition Navigation (GAN) software, and a highly sensitive and mobile GPS (with DGPS) was used for WAAAS corrections. The processing steps included automatic gain control (AGC), time variable gain (TVG), normalized and trace-mixed equalizations, bandpass filtering of $1000-4000 \mathrm{~Hz}$ and source-receiver depth correction.

\section{The High-resolution Seismic Reflection Anomalies Of Shallow Gas}

Distinct seismic anomalies of shallow gas were observed on the high-resolution data (Figs. 3-10) acquired on Lake Erçek (Fig. 2b). The most evident shallow, gas-related features on the seismic profiles were found at water depths ranging from $20-25 \mathrm{~m}$ to $35-40 \mathrm{~m}$. Gas-charged sediments manifest themselves in high resolution imaging through: (a) enhanced reflections (ER); (b) seismic chimneys (SC); (c) acoustic blanking (AB) and acoustic turbidity (AT); (d) strong reflector (SR); and (e) pockmarks, including both surface (SP) and buried (BP) pockmarks.

\section{(a) Enhanced reflections (ER, layer enhancement)}

Distinct patterns of high-amplitude reflections, which are concordant with the depositional bedding of the soft sediments, occur mostly in the deep part of the lake (Figs. 3-5, 6b and 7). These high-amplitude reflections are discontinuous features with a maximum of $1-2 \mathrm{~km}$ in length. 
This type of gas signature is represented by high coherency of seismic reflection pattern, causing high amplitude layers. This is mainly due to the gas front at the upper part of the gas-charged sediments. The gas front has a strong reflection pattern with high amplitude, that is even stronger than the reflection from the lake bottom and has been reported to be up to 1.2 to 8 times greater. The enhanced reflection reveals a sharp interface with high reflection coefficient and high acoustic impedance contrast due to the presence of gas, causing "reverberation or ringing" of the seismic signal. The reverberation appears as closer multiples, observable as seismic reflections with lowered amplitudes in sections (Figs. 3, 4, 5a and 7a).

\section{(b) Seismic chimneys (SC)}

Seismic chimneys, characterized by strong vertical disturbances of acoustic wipe outs, that is strongly reduced reflection amplitudes, occur as narrower zones crossing the sedimentary bedding (Figs. 3, 4, 5b, $6,8,9 b, c$ and $10 b, c)$. Some SCs are found closely associated with enhanced reflections (Fig. 6b), some SCs are most common immediately below pockmarks (Figs. 9 and 10), and some are found either as areal clusters of chimney groups (Figs. 5b, 6a and 8) or as isolated individual SCs (Figs. 3 and 4), having less than 1-m in width and $10-15 \mathrm{~m}$ in height.

This type of gas signature represents vertical to sub-vertical columns of noisy seismic signature due to the scattering effect on acoustic energy of localized gas saturation zones. Low amplitude reflection patterns and highly variable dip- and azimuth of the reflections characterize SCs, indicating vertical to sub-vertical upward motion and accumulation of gas.

\section{(c) Acoustic blanking (AB) and acoustic turbidity (AT)}

Acoustic blanking (AB) and acoustic turbidity (AT) are two of the most prominent seismic anomalies produced by shallow gas in the surveyed area. Complete wipe out reflection characteristics of seismic signals characterize these anomalies (Figs. 3, 4, 5a, 6b, 7b, 8 and 9b). AB occurs in wide columnar and also narrow vertical disturbances, and is related to shallow degassing, while AT indicates gas-disrupted sediment packages through which the gas propagates to the upper layers (gas-charged sediments; Hovland, 1981a, b; Hovland, 1984; Hovland and Judd, 1988).

$A B$ represents a masking of underlying depositional settings beneath gas-charged sediments. This is mainly due to high attenuation and/or high reflection from the overlying deposits. AB appears as upper, high amplitude reflections, but lower than this signal penetration is not possible due to absorption and scattering of seismic energy at the top of the $A B$ anomaly. Hence, beneath the upper part of the gascharged sediments, no depositional stratification and/or bedding can be identified. The complete loss of seismic energy in these blanking sections is the reason why $A B$ appears as an acoustically transparent zone in many sections. Due to the high reflection coefficient of the gas front, several reverberations accompany the AB (Figs. 3, 4, 5a and 7a). However, AT represents a chaotic cloud of seismic reflection fragments, with few or no multiples, within the mud deposits and on gas intrusions with variant extent leading to bedding or strata blurring, and consisting of point scattering of various amplitudes. Seismic 
signal attenuation is relatively smaller when caused by AT compared to AB. Distinct reflection fragments delineate the top of the AT.

\section{(d) Strong reflector (SR)}

An anomalously strong reflector (SR) is observed in only a few seismic sections from the W-part of the surveyed area (Figs. 7a and 8). This reflector is highly continuous and laterally extensive, lying concordantly to the depositional bedding. This reflector, similar to what was observed with the ER, follows the lake bottom, appears very strong, and terminates slightly with distance by no more than $4-5 \mathrm{~km}$ in length. This reflector seems to follow the contour of the lake floor as the one of the most obvious gasrelated reflection patterns observed on the seismic profiles. Hence, this reflector represents a very shallow ER indicating the presence of shallow free gas, probably accumulating below a lower-permeability sediment layer (e.g., Hovland, 1992, 2008) surrounding the W-part of the lake. The only difference between the SR and the ER appears to be that SR is present over a larger area while the ER is only in present in limited areas. They both occur at the same stratigraphic level, suggesting that there is some sort of lithological and/or permeability mechanism which determines their occurrence.

\section{(e) Pockmarks - surface (SP) and buried (BP) pockmarks}

Two types of pockmarks were observed in the surveyed area (Figs. 5, 7b, c, and 8-10) which are surface (SP) and sub-surface (buried, BP) pockmarks (Hovland, 1981a, b, 1982, 1984; Hovland and Judd, 1988). SPs are characterized by elongated, $\mathrm{u}$ - and v-shaped lake bottom depressions which appear as incised, smaller undulations on the lake floor (Figs. 9 and 10), while the BPs are buried and relatively older features, locally filled with host sediments (Figs. 5, 7b, c, and 8). Smaller, crest-like, mounded highs immediately below the BPs are observable in a few locations (Figs. 5b, 7c and 8) and are associated with the development stages of the pockmark formation (Hovland, 1981a, b, 1982, 1984, 1989; Hovland and Judd, 1988). The BPs are thus anomalous because they do not conform to the formation mechanism for normal pockmarks (Hovland, 1981a, b, 1982, 1984, 1989; Hovland and Judd, 1988). The pockmarks are observed in water depths of greater than about $25 \mathrm{~m}$ and are clustered in the SE-part of the lake (Figs. 9 and 10). In the surveyed area, enhanced reflections and seismic chimneys locally accompany the observed pockmarks (Figs. 7b, c, 9 and 10), which may be caused by vertical sub-surface weakness zones.

The pockmarks are morphologically remarkable, isolated patchy structures resulting from gas leaking through deposits and/or accumulation of the type 3 gas bubbles which are known to affect overall depositional mechanics. The fluids and/or gas cannot move and/or escape without percolating through muddy and other fine-grained deposits and finally, the disturbance creates a widespread area classified as a pockmark and characterized by distinct surface pattern structure.

The different manifestations of types of gas occurrence (types 1, 2 and 3) in the sediments below Lake Erçek can be characterized using a combination of the previously described gas signatures. These different manifestations appear at variable depths and to different extents, co-exist with each other, 
change abruptly and/or gradually in some places, and undergo spatial variation. The gas, regardless of the types of occurrence, appears in the entire column of the lacustrine deposition. In seismic section, as observed in Fig. 4, the separation between the gas-bearing layer and lake-floor gradually increases with an increase in water depth due to the increasing pressure, which favours gas entrapment within the sediment pores.

Figure 11 shows the basinal distributional patterns of the shallow gas anomalies observed in the study area, compatible with the morpho-physiographic characteristics of the Lake Erçek basin. Figure 12 shows a simplified map of the structural deformation and faulting patterns of the lake, superimposed on the distributional pattern of the shallow gas shown in Fig. 11 and the bathymetry shown in Fig. 1b.

\section{Discussion}

\subsection{High-resolution seismic images of shallow gas}

\section{Seismic chimneys}

SCs, which are generally interpreted as gas/fluid-related vent structures generated by upward propagation of gas and/or fluids at shallow levels ( 15-20 m sediment thickness) (Hustoft et al., 2010; Çukur et al., 2013b), most probably indicate shallow-seated gas deposition and represent a link to reservoir rocks associated with mantle-sourced fluids or volatiles. In the surveyed area (Fig. 11), particularly in the W-and E-boundary sections of the lake, it is postulated that SCs are associated with relatively more permeable and unconsolidated depositional bedding and the observed extensional faults-fractures (Fig. 12), facilitating the upward migration of gas (Toker and Tur, 2018). SCs are mainly responsible for pockmark formations, both active (SP) and passive (BP), and function as conduits for gas-fluid emissions in the lake surface and sub-surface depositional levels, depending on local stratigraphy and reservoir feedback.

\section{Pockmarks}

Pockmarks are u- or v-shaped, undulating lows, incised on the lake-floor that are generated by escaping gas associated with pore fluids (Jobe and Lowe, 2009; Hovland and Judd, 1988; Fleischer et al., 2001; Çukur et al., 2013b). The formation mechanism of pockmarks depends strongly on areal or local sedimentation processes, such as deposit types, permeability level, consolidation degree, thickness, pore pressure and fluid content. SPs are most common in the SE-part of lake near the delta (E-margin) (Fig. 11), indicating that the lake floor morphology may have been made of fine-grained clay and silty sediment packages (Croker et al., 2005; Çukur et al., 2013b), through which a sufficiently energetic accumulation of gas may erupt, as long as the reservoirs provide the feedback. In this case, depositional sequences, such as fine-grained sediments, over the delta sedimentation which consists of coarsegrained sediments will act as a seal. The surface pockmarks are very rare in the NW-part of lake, indicating unconsolidated and highly permeable piles of soft sedimentary bedding, through which the gas accumulations are much more easily propagated and no energetic outburst is required. Interestingly, the buried sub-surface BP in the NW did not evolve to become the SP-type pockmarks found in the SE 
(Fig. 11), probably due to either the highly permeable filling, or possibly because feedback ceased, which may have occurred because migration of fluids/gas ceased or became much less energetic.

\section{Acoustic blanking and turbidity}

Acoustic blanking and acoustic turbidity are the seismic signatures of acoustic gas masking, indicating the presence of free gas and thus, gas-charged sediments (Fig. 11) (such as the gas bubbles entrapment and absorption from Taylor, 1992; Hovland and Judd, 1988). Such seismic signatures are generally interpreted to be due to biogenic gas, resulting from the decomposition of muddy organic materials. Acoustic blanking and acoustic turbidity are also likely dynamic signatures evolving over time as the solubility of dissolved gases respond to hydrostatic pressure cycles in the lake basin (see the similar model for Lake Van basin by Çukur et al., 2013b). The high-frequency, lake water pressure load-unload cycles, such as high-energy transgressive-regressive intervals, may have the capability to force dissolved gases into a free gas phase and, thus, result in bubble formation. Given these hypotheses, we propose that the rapid and uneven water level drop in the lake due to local uplifts through mechanisms including basement highs and onlap filling deposits in the lake (Toker and Tur, 2018) may have produced the acoustic gas masking. However, the processes we propose here to explain the presence of gas bubbles are relatively slow processes and likely occurred under continuing sedimentation. We should include the ongoing sedimentation in our hypothesis and the continuously increasing burial depth of the stratigraphic level at which the gas bubbles occur. If we take into account shorter term dissolution cycles, possibly driven by seasonal temperature changes or even pressure changes, as documented in Eckernförde Bay, for example, this can lead to dissolution of gas in the pore waters, which can then migrate through the sedimentary column, perhaps through compaction-driven upward flow, until the gas re-exsolves (maybe only temporarily) at a higher stratigraphic level.

\section{Enhanced reflection}

The presence of a free phase of dissolved gases, mentioned above, may indicate a substantial variation in acoustic impedance, creating high frequency and high amplitude enhanced reflections (Wood and Ruppel, 2000; Çukur et al., 2013b). A few buried pockmarks (Figs. 7b, c), isolated chimneys and chimney clusters (Fig. 6b) accompany some enhanced reflections, suggesting a venting process activated through the sedimentary bedding packages (Figs. 3-8). These enhanced reflections also suggest that gas accumulations are generated locally in the depositional bedding (Fig. 11). Previous studies have reported findings including similar reflections recorded at Lake Van basin (Çukur et al., 2013b) and even above oil/gas reservoirs in the Muş Basin (Kurtman et al., 1978).

\section{Strong reflector}

The strong reflector that we anomalously observed typically appears to simulate or parallel the lake bottom. However, this feature was only observed in the W-section of the lake and is very similar to the enhanced reflections in frequency-amplitude-length (Figs. 7a and 8). The only difference appears to be in the extent of the two types of reflection. We suggest that this reflector is an extended version of the 
enhanced reflections described previously (Hovland and Judd, 1988; Hovland, 1992, 2008) in and around the W-sections of the lake (Figs. 11 and 12), where the N-S-striking, normal faults and related basin subsidence have also been reported by Toker and Tur, (2018).

\section{Velocity pull-down effect}

This is a type of velocity distortion seen throughout the high-resolution seismic sections, indicating a downward deflection of reflections below the low-velocity, gas-charged layer, as described by Tóth et al., (2014). This distortion is not evidenced in the lake. This may be due to a relatively thinner layering of the gas-charged sediments, since the low velocity layer-travel path is much shorter than the total travel path, as previously described by Tóth et al., (2014).

In Lake Erçek, the undisrupted, unconsolidated and thinned depositional piles of sedimentary bedding observed above the gas-related features, such as buried pockmarks, enhanced reflections, and acoustic blanking do not appear to be associated with free gases (e.g., Figs. 3, 4, 6, and 7). This observation suggests that a major outgassing may have occurred before the deposition of the uppermost sedimentary layering or that the gas front, as a dynamic feature moving through time, may be simply depth- and temperature-controlled or only lithologically-controlled, for example by the presence of a permeability barrier. This may explain the anomalous spatial distribution of the buried pockmarks, being present in the NW-part and absent in the SE-part of the lake (Fig. 11). In the SE area surface pockmarks are observed, due to possible impermeable deposits, and a major outgassing process has been actively continuing and deforming the lake floor, while in the NW section perhaps the process occurred in the past. The NW-section of the lake favors the presence of buried passive pockmarks and acoustic gas masking (e.g., gas bubbles) in possible permeable deposits, while the SE-section of the lake favors the presence of surface active pockmarks and an ongoing gas migration processes, such as active dissolution of gas bubbles associated with possible impermeable deposits. We propose that the difference in the formation of pockmark styles between NW and SE mainly depends on the fault-controlled margin boundary uplifts (Fig. 12) (e.g., basement highs by Toker and Tur, 2018) as active sediment sources from W- and NW-parts, continuous delta deposition in the E-area of the lake and, thus structural control of overall sedimentation characteristics on the gas-related deformation and migration processes in the Lake Erçek basin. Hence, we suggest that extensional structural deformation may have locally activated the free phase of gas and caused extensive gas accumulations through the sedimentary layering. This is discussed further in greater detail below.

\subsection{Possible sources of the free gas}

In the lake, the acoustic turbidity areas shown by Figs. 3 and 6-9 indicate that the gas-charged depositional packages are represented by strong upper (top) fragmentary reflections, masking lower reflections, in spite of high acoustic impedance, showing the occurrence of free gas. We consider that, in general, low concentrations of discrete gas voids in shallow, fine-grained deposits causes acoustic turbidity areas (Hovland and Judd 1988), similar to the samples reported by Vardar and Alpar, (2016). However, deposits with low quantities of gas saturation may yield the same and/or similar seismic 
images to those with a high degree of gas saturation (Judd and Hovland 1992; Missiaen et al. 2002; Vardar and Alpar, 2016). Hence, it is impossible to estimate and interpret the amount of gas saturation in shallow deposits using seismic reflection profiles only. As reported by previous studies and discussed elsewhere (e.g., Vardar and Alpar, 2016), further studies, such as drilling, sediment core samples, or chromatography, are required.

Considering that the existence and amount of free gas in any medium depend on two basic controlling factors: (a) the total concentration of gas molecules in sediments, and (b) the solubility of the gas (Visnovitz et al., 2015), vertical distribution of free gas in the entire depositional column could be of two kinds, as proposed by (Visnovitz et al., 2015). These are (i) bubble migration, which involves upward motion of gas from the deeper part to the upper part of the mud, resulting in increasing concentration towards the top, or (ii) molecular diffusion, which will move gas in the direction of lower concentration, down a concentration gradient, and leads to decreasing concentration of gas with increasing distance from the source, for example as found in the mud of the Lake Balaton (Visnovitz et al., 2015 and references therein). Accordingly, possible sources of free gas for Lake Erçek sediments, which might have been deposited in a paleo-lake setting, possibly during the period of last glacial maximum (e.g., so similar to a case of the paleo-Marmara lake by the Imrali sill, as reported by Vardar et al. 2014 and Vardar and Alpar, 2016), can be considered as microbial decomposition of organic matter and $\mathrm{CO}_{2}$ transported by fluid migration from deeper layers. In addition, the physical dissolution process, bacterial consumption of methane, continuous upward migration of small gas bubbles, molecular diffusion and uneven degassing processes due to recordable mechanical impacts, including earthquakes, tectonic activity and storms, could be considered as the main reasons for major sinks of the gas (Visnovitz et al., 2015) and thus its distribution in the lake deposits. The following subsection provides a discussion of the relationship between the source of the free gas and the structural deformation of Lake Erçek.

\subsubsection{Structural factors}

The maps obtained from the high-resolution data, as given by Figs. 11 and 12, indicate gas accumulation in correspondence with the structural deformation of the lake (Toker and Tur, 2018). The gas migrates through the depositional column along the normal faults, which allow fluids to flow vertically and/or subvertically across deposits. Such migration pathways are well indicated by evidence of gas/seismic chimneys occurring in close relationship to the faults, as proposed by Anka et al., (2014). The stratigraphic layering and/or bedding style also affects the presence or otherwise of seismic chimneys. In this case, the gas migrates freely within the entire depositional column and results in pockmarks on the lake floor. In some areas, fine to very fine silty layers may act as a trapping cap to prevent the escape of gas bubbles to the surface (Lodolo et al., 2012). These gas migration pathways coincide with the observed seismic chimneys and pockmarks and reach as high as the lake bed, feeding the observed pockmarks in the faulted marginal areas of the lake. This type of fault-related seismic chimney feeding pockmarks was also observed in the Colorado Basin (offshore Argentina Margin, South America) through 3D seismic modelling by Anka et al., (2014). 
In contrast, the distributional pattern of gas migration pathways may be determined by specific vertical and/or sub-vertical fracture systems. These fracture systems may change, for example the opening or closing of fractures over time, in the sedimentary column and will be associated with presence of gas (Best et al. 2006; Jaśniewicz et al., 2019). However, faults, rather than fractures, may either create high permeability zones that facilitate migration (e.g., the Lake Balaton, the Szemes basin and the Siofok basin, as observed by Visnovitz et al., 2015) or form low permeability barriers forcing groundwater flow towards the surface (e.g., offshore Balatonvilagos and Balatonfoldvar, as reported by Visnovitz et al., 2015). Hence, the occurrence of shallow gas in the sediments could be linked to the presence of faults and, to some degree, to fractures associated with the E-W extensional deformation that crosses the Wand E-margins of the lake, along which gas or fluids could rise to the surface (e.g., Lodolo et al., 2012). In the area of the Gdańsk deep, for example, several fault zones and their displacements, at depths of 30 to $100 \mathrm{~m}$, lead to the presence of gaseous methane and higher hydrocarbons in shallow sediments (Domżalski et al. 2004; Pig-Pib, 2008) following migration from deep layers (Jaśniewicz et al., 2019).

\subsection{The main controlling elements}

\subsubsection{Seismicity-driven overpressure control}

As shown in Figs. 11 and 12, the ESE-part of the lake is affected by normal fault systems, and the surface pockmarks are generally almost circular in shape and smaller in size. The WNW part is characterized as an area of individually elongated and isolated pockmarks, vertically stacked, and shallow buried pockmarks, which are presently non-active and have been filled by recent deposits due to cessation of gaseous expulsion (e.g., Çifçi et al., 2003). As suggested by Çifçi et al., (2003) for both the surface and buried pockmarks, an erupted pockmark will become buried until further eruption and these cycles will continue periodically. In this way vertically stacked pockmarks are formed (Çifçi et al., 2003).

In Fig. 12, the buried pockmarks, observed in vertically stacked form in the sedimentary column around the vicinity of the N-S oriented normal faults, indicate non-continuous migration of gas to the lake floor, as in the mechanism described above (e.g., Çifçi et al., 2003). This reactivation of gas migration may occur particularly during possible overpressure conditions. This overpressure control may be concurrent with strong historical and/or recent earthquakes (Vardar and Alpar, 2016), which have been shown to have had a marked effect on the W- and E- parts of the lake (e.g., Toker et al., 2017b). Similar forms of buried pockmarks have also been observed in the Adriatic Sea (Curzi and Veggiani 1985), the W-part of the Sea of Marmara (e.g., those given by Altınok and Alpar, 2006; Vardar and Alpar, 2016), the slope of the Gulf of Cadiz (Baraza and Ercilla 1996) and the pockmark plateau on the Turkish Shelf (Çifçi et al., 2003).

Given that Lake Erçek is tectonically highly active and asymmetrically developed as the W-E extensional half-graben basin due to N-S regional compression (Toker et al., 2017a, b; Toker and Tur, 2018 and references therein), seismically active, regional, tectonic deformations could have a significant impact on stress-strain conditions of the lake, and thus, modify and/or regulate the overpressure conditions cyclically in the lake (e.g., Çifçi et al., 2003 for the case of the North Anatolian Fault, Turkey) resulting in periodic interruption and/or reactivation of gas movement. This explanation for periodical variations in 
overpressure conditions suggests that seismologically driven periodical overpressure generated gas/fluid escape to the lake floor (Çifçi et al., 2003). Indeed, some remarkable events and/or variations in local stress-strain regime (e.g., due to the great earthquakes; Mw 7.1, the 2011 Van mainshock-aftershock sequence by Toker, 2013, 2014, 2017, 2021; Toker et al., 2017b and references therein and/or the deepseated, large-scale vertical disturbances; doming hot asthenosphere beneath the lakes in Toker and Şahin, 2019 and references therein) near Lakes Van and Erçek areas in and along the E-Anatolia could considerably change the overpressure conditions in the pockmark areas of the lake. This could conceivably have contributed to an increase of the pore pressure in the gas-charged deposits and, hence, the expulsion of the accumulated gas via pockmarks (e.g., the evolution and formation of surface and buried pockmarks proposed by Çifçi et al., 2003 for eastern Black sea, the Turkish shelf).

\subsubsection{Faulting-driven depositional control}

In Lake Erçek, as shown by Figs. 11 and 12, seismic chimneys are controlled both by faulting elements and also by vertical-horizontal depositional factors. Thus, they migrate freely through the entire depositional column and finally reach the lake floor resulting in surface pockmarks. However, it is interesting to note that no surface pockmarks are evident in and along the fault-controlled margin of the lake in the W. As mentioned previously, the reason for this is that, either an impermeable depositional layer prevents a further direct migration along the normal faulting in the W-margin or that the faulting is somehow closed (Anka et al., 2014). For example, Clayton and Hay (1994) proposed that faults buried deeper than $200 \mathrm{~m}$ act as seals and not as migration pathways, as the horizontal stress is normally sufficient to close them (Anka et al., 2014).

An effective gas movement and distribution system is, in general, driven both by regional and/or local tectonic faults and/or local polygonal networks acting as flow conduits for the migrating gases, as observed in the Barents Sea by Berndt et al. (2003) and also by Ostanin et al. (2012) (Anka et al., 2014). In and along the W-part of the lake, except for surface pockmarks, extensional normal faulting allows the gas to migrate vertically, for example via seismic chimneys. Thus, diffuse gas migration appears to occur along the faulting with further horizontal migration, as suggested by enhanced reflections together with seismic chimneys, where diffuse high-amplitude reflectors suggest gas accumulation, for example in areas of acoustic turbidity. In this case, the gas appears to migrate directly through the sediments with no structural control that might facilitate fluid flow (Anka et al., 2014). Similar structures are reported within the main depocenter in the Orange Basin (Kuhlmann et al., 2010) where the gas also seems to move up freely through the sedimentary column with no structural element (Anka et al., 2014). Also, the stratigraphically controlled gas chimneys in the Colorado Basin occur within the main depocenters, as reported by Anka et al., (2014).

In addition to depositional control, a comparable fault-controlled pockmark population reported in the slope area of the Orange Basin (Kuhlmann et al., 2010; Hartwig et al., 2012) is well documented by Anka et al., (2014). Hartwig et al. (2012) found that, in the Orange Basin, a large field of buried pockmarks and related fluid flow features are associated with tectonic structures (e.g., gravitational slope fault zones). For example, in the Colorado Basin, seafloor depressions at the hanging wall block of the fault zones 
have been interpreted as pockmarks (Anka et al., 2014). Similar depressions have also been observed in a number of seismic lines where the pockmarks appear to be aligned with the faults, supporting the proposed fluid conductive nature of the system (Anka et al., 2014). Pockmarks related to faults have been described in the eastern South Atlantic as well (Gay et al., 2007; Pilcher and Argent, 2007) and are reported to act as pathways for fluid migration (Anka et al., 2014).

In conclusion, the presence of free gas at shallow depths in Lake Erçek is basically controlled by structural deformations, such as through faulting activity, that provide the faulting-driven depositional control together with seismic events, such as earthquakes, that provide the seismicity-driven overpressure control. By these mechanisms the shallow gas is distributed both vertically and horizontally and the final observed distribution is shaped by asymmetric depositional and stratigraphic factors.

\subsection{Tectono-thermal implications for Lakes Van and Erçek}

The N-S-striking normal faults are evident in the seismic reflection profiles in and along the W-and $\mathrm{E}$ margin boundaries of the lake (Fig. 12) (Toker and Tur, 2018), where gas-related features, particularly the pockmarks, are peculiarly extended from the $\mathrm{SE}$, characterized by active pockmarks to NW where passive pockmarks are prevalent (Fig. 11). In the lake area, the W-E extensional stresses driven by N-S compressional regime resulted in faulted-fractured pathways and cracked sedimentary beddings, through which deeply-sourced and thermally-produced gases may be assumed to be vertically propagated, migrated and accumulated at shallow depths (see Toker and Şahin, 2019 for tectono-magmatic Lake Van and Erçek regions of E-Anatolia). This is, in fact, the same model proposed for magma intrusion-extrusion through the thick sedimentary columns of the Lake Van basin (Toker et al., 2017a).

Following the extensive crustal tomographic studies of tectono-magmatic Lakes Van and Erçek basins in E-Anatolia by Toker and Şahin, (2019), we may attribute such a hypothesis of shallow thermal gas distribution and the feedback capacity of this system to high-temperature crustal and basinal deformation events (e.g., thermogenic gases by Davis, 1992) and to the decompositional fracturing of organic fragments at relatively large overburden depths of around $\sim 500 \mathrm{~m}$ to $1000 \mathrm{~m}$, thick enough to allow thermogenic gas formation. We argue that most of the observed gas accumulations, not only in the Lake Erçek basin, but also in the adjacent Lake Van basin, might have been thermo-genetically formed, rather than through low-temperature biogenesis. Here, our high-temperature scenario (e.g., low crustal velocity data from Toker and Şahin, 2019) for favorable conditions for the formation of thermogenic gas is completely different from the alternative scenario, which is based on low heat flow into Lake Van (Kaden et al., 2010; Çukur et al., 2013b) and then into adjacent Lake Erçek. Despite a large amount of core data and an extensive series of similar publications performed by a scientific working team of the International Continental Drilling Project (ICDP) PaleoVan cores (ICDP PaleoVan project by Litt et al., 2009, 2011, 2014; Çukur et al., 2013a, b and references therein), the ICDP project team applied low heat flow and low temperature scenarios to the core results of drilled sediments from the Lake Van basin without taking into account evidence of extensive thermal expansion of the supersaturated gases within these drilled sediments, suggesting a possible thermogenic origin for the gas deposits, as had been previously reported (e.g., Çukur et al., 2013a, b). 
In the study area, it is possible to associate gas-related features, in particular the enhanced reflections and seismic chimneys, to tectono-thermal genesis as a basin-wide activation of deep-seated processes to modulate the preferential emission of deep-seated fluids, such as primitive mantle-sourced volatiles, as has been shown in accumulating mantle fluids in Lake Van (Kipfer et al., 1994; Tomonaga et al., 2011; Çukur et al., 2013b). The observation of mantle-derived He in the Lake Van studies supports our hypothesis of a thermogenic origin of the shallow gas in Lake Erçek. For example, in the adjacent Lake Van basin, the observed gas anomalies, such as seismic chimneys and enhanced reflections, were closely associated with higher He fluxes (Tomonaga et al. 2011; Çukur et al., 2013b) and as an indicator of highly permeable sediments at depth (Tomonaga et al. 2011). Moreover, the observed acoustic gas masking, indicating gas-charged sediments in the study area (Fig. 11), showed extensive columnar and vertical disturbances probably caused by energetic degassing processes, which could in turn have been caused by movement thermogenic fluids at some time, as proposed for Lake Van by Tomonaga et al., (2011). In addition, in the study area acoustic gas masking was accompanied by enhanced reflections and seismic chimneys, suggesting that the gas emissions were produced in the lowermost levels of the depositional layering. The pockmarks appear to evolve from the active and younger to the passive and older type along a SE to NW strike, and could have been the result of impermeable delta sedimentation, probably containing a high organic content, a biogenic source of gas previously deposited by tributaries inflowing into the $\mathrm{E}$ - and SE-sections of the lake.

Finally, in the Lake Erçek basin, the observed gas-related features at shallow depths may be attributed to a number of formative mechanisms such as delta sedimentation trapping gases, fault-controlled block uplift and deep-seated deformation producing high-temperatures. These observations may also be valid for those results obtained in the Lake Van basin. In the other words, the shallow gas deformation and migration events seen in both Lakes Erçek and Van may be, at least partly, associated with tectonothermally driven processes (Toker and Tur, 2018; Toker and Şahin, 2019; Toker et al., 2017a).

\section{Conclusions}

In Lake Erçek, significant shallow deposits of gas in lacustrine sediments have been discovered together with results showing the characteristics of their distinct seismic expressions. The gas deposits were identified through recognition of the significance of the high acoustic impedance and high amplitude reflection with reversed polarity at the sediment/gas-charged sediment interface. The high-resolution seismic reflection anomalies of shallow gas, found at water depths ranging from 20-25 m to 35-40 m indicate significant variations in how shallow gas manifests in high-resolution profiles, even over relatively enclosed areas, such as in the WNW-part of the lake. These characteristics include enhanced reflections (ER), seismic chimneys (SC), acoustic blanking (AB) and acoustic turbidity (AT), strong reflector (SR), and both types of pockmarks, surface (SP) and buried (BP) pockmarks.

The gas-induced acoustic impedance variations result in high amplitude reflections, representing the enhanced reflections, which are most densely observed in the NW-corner of the lake. Seismic chimneys accompany some enhanced reflections. The vertical and thinned columnar disturbances of blanking in 
reflection amplitude represent seismic chimneys, occurring widely in the lake, both in the deep basin and also in faulted areas. This suggests the fluid flowing and migrating upward through both highly permeable deposits at basin center and through fault-associated pathways in the W-and E-parts of the lake. Some of the seismic chimneys are closely associated with pockmarks, and are characteristic of active vent structures. Widely diffused, chaotic seismic reflections are acoustically gas-masked features consisting of acoustic blanking and/or acoustic turbidity, which are observed where all gas-related features are detected. Acoustic blanking shows vertical columnar disturbances due to previous degassing, while acoustic turbidity is extremely diffuse, indicating gas-charged sediments. These gasmasking features coincide with the deep basin morpho-topography of the lake, extending from SE to NW. The strong reflector, very similar to the enhanced reflections, simulates the lake bottom, but is only identified locally surrounding the W-section of the lake, where an extended type of enhanced reflections is apparent as this strong reflector, suggesting shallow-seated gas in the lake. The u- and v-shaped, incised bathymetric lows on the lake-floor represent the surface (active) pockmarks, and are only observed in the SE-part of the lake, while the buried (passive) pockmarks, are found within the sediment and are not evident on the lake bed surface, represent a development stage of the pockmarks, and are only observed in the NW-part of the lake. Shallow gas migrates horizontally and vertically through the extensional normal faults in the W- and E-parts of the lake and within the vertical and/or sub-vertical fractures and through the depositional column, and then, reaching the lake bed, results in the observed surface pockmarks. The surface pockmarks are observed in expulsive form, only in the extensionally faulted Emargin. The presence of buried pockmarks in sediments indicates that gas migration to the depositional column was non-continuous and periodically repeated, showing variations in overpressure conditions.

The shallow gas presence in Lake Erçek is, in general, influenced by a series of several factors. These include sedimentation style, sedimentary structure and faulting activity. Shallow gas distribution is basically controlled by structural deformations, such as faulting activities, that provide the faulting-driven depositional control and seismic events, such as earthquakes, that provide the seismicity-driven overpressure control. The shallow gas is then both vertically and horizontally distributed and, finally, distribution is shaped by asymmetric depositional and stratigraphic factors. Hence, this research has raised some new questions and has also provided complementary information about the possible source of the shallow gas observed in both Lake Van and Lake Erçek and the mechanisms of pockmark occurrences. We propose a tectono-thermal genesis model that can hypothetically explain, at least in part, the observed gas-related anomalies in Lakes Erçek and Van. We suggest that the observed pockmarks should be targeted for valuable geochemical proxies to reconstruct the paleo-environmental conditions in Lake Erçek and the adjacent Lake Van areas. However, these will require further sedimentary drilling and chemical studies for further analyses.

Lastly, the lacustrine depositions of Lake Erçek, together with Lake Van, have previously been shown to be important because of the spatio-temporal information therein, their well-constrained boundaries in sedimentation and the datable depositional archives of the paleo-climatic and hydrological changes which have affected these lakes. The present study has added to the importance of these lacustrine depositions by identifying the characteristic seismic fingerprints of significant deposits of associated 
gas, together with a proposed mechanism for the distribution of the gas deposits within the lake bed sediments.

\section{Declarations}

\section{Acknowledgements}

The authors would like to thank Yuzuncu Yıl University, Scientific Research Projects-Coordination Unit (SRP-CU), Van, Turkey for supporting the Lake Erçek Seismic Survey project, 2015 (Toker, 2015) and the research vessel scientific crew during the survey. This research was undertaken as part of a multidisciplinary LESS-2015 project of Istanbul University Cerrahpaşa (IU), Department of Geophysical Engineering, Istanbul and Yuzuncu YIl University (YYU), Division of Earth Physics, Van (Turkey). The LESS-2015 project was supported by Research Fund of the Yuzuncu Yıl University (under Scientific Research Project Number: 2015-MiM-B119), and was partly supported by the University of Oulu (Oulu, Finland) post-doctoral research grant. The authors offer their greatest thanks to the editors and the two anonymous reviewers for their constructive comments and suggestions, which helped to improve the manuscript. The maps in this paper were generated using public domain generics.

\section{References}

Abegg F. and Anderson A.L. 1997. The acoustic turbid layer in muddy sediments of Eckernfoerde Bay, Western Baltic: methane concentration, saturation and bubble characteristics. Marine Geology 137, 137147.

Altınok, Y., and B. Alpar (2006), Marmara Island earthquakes, of 1265 and 1935; Turkey, Nat. Hazards Earth Syst. Sci. 6, 6, 999-1006, doi: 10.5194/nhess-6-999-2006.

Anderson A.L, Abegg, F., Hawkins, J.A, Duncan, M.E, Lyons, A.P., (1998) Bubble populations and acoustic interaction with the gassy floor of Eckernförde Bay. Cont. Shelf Res. 18 (14-15): 1807-1838.

Anderson A.L. and Bryant W.R. 1990. Gassy sediment occurrence and properties: Northern Gulf of Mexico. Geo-Marine Letters 10, 209-220.

Anderson A.L. and Hampton L.D. 1980. Acoustics of gas-bearing sediments II. The Journal of Acoustical Society of America 67(6), 1880-1903.

Anka, Z., Loegering, M. J., di Primio, R., Marchal, D., Rodríguez, J. F., Vallejo, E., 2014. Distribution and origin of natural gas leakage in the Colorado Basin, offshore Argentina Margin, South America: seismic interpretation and 3D basin modelling. Geologica Acta, V.12, No 4, ALAGO Special Publication, 269-285, doi: 10.1344/Geologica Acta2014.1 2.4.1.

Baltzer A., Tessier B., Nouze H., Bates R., Moore C. and Menier D. 2005. Seistec seismic profiles: a tool to differentiate gas signatures. Marine Geophysical Research 26, 235-245. 
Baraza, J., Ercilla, G., (1996) Gas-charged sediments and large pockmark-like features on the Gulf of Cadiz slope (SW Spain). Mar Petrol Geol 13:253-261.

Berndt, C., Bünz, S., Mienert, J., 2003. Polygonal fault systems on the mid-Norwegian margin: A long term source for fluid flow, in P. Van Rensbergen, R. Hillis, A. Maltman, and C. Morley, eds., Subsurface Sediment Mobilization: Geological Society Special Publication, 216, London, UK, Geological Society of London, 283290.

Bertin X. and Chaumillon E. 2005. New insights in shallow gas generation from very high resolution seismic and bathymetric surveys in the Marennes-Oléron Bay, France. Marine Geophysical Researches 26, 225-233.

Best, A.I, Richardson, M.D, Boudreau, B.P et al (2006) Shallow seabed methane gas could pose coastal hazard. Eos 87 (22): 213-215.

Best, A.I., Tuffin, M.D.J., Dix, J.K., Bull, J.M., (2004), Tidal height and frequency dependence of acoustic velocity and attenuation in shallow gassy marine sediments. J. Geophys. Res. 109 (B8): B08101. https://doi.org/10.1029/2003JB002748.

Boudreau, B.P, Algar, C, Johnson, B.D et al (2005) Bubble growth andrise in soft sediments. Geology 33(6):517-520. https://doi.org/10.1130/G21259.1.

Chun, J.H., B.-J. Ryu, C.S. Lee, Y.J. Kim, J.Y. Choi, N.K. Kang, J.J. Bahk, J.H. Kim, K.J. Kim, and D.G. Yoo, (2012), Factors determining the spatial distribution of gas-charged sediments in the continental shelf off southeastern Korea, Mar. Geol. 332-334, 27-39, DOI: 10.1016/j.margeo.2012.06.004.

Çifçi, G., Dondurur, D., Ergün, M. (2003), Deep and shallow structures of large pockmarks in the Turkish shelf, Eastern Black Sea, Geo-Mar Lett (2003) 23: 311-322, doi: 10.1007/s00367-003-0138-x.

Clayton, C.J., Hay, S.J., 1994. Gas migration mechanisms from accumulation to surface. Bulletin of the Geological Society of Denmark, 41, 12-23.

Cole, D, Stewart S.A, Cartwright, J.A (2000) Giant irregular pockmark craters in the Palaeogene of the Outer Moray Firth Basin, UK North Sea. Mar Petrol Geol 17:563-577.

Curzi, P.V, and Veggiani, A. (1985) I pockmarks nel mare Adriatico centrale. Acta Nat Ateneo Parmense 21:9-90.

Croker, P.F., Kozachenko, M., Wheeler, A.J., 2005. Gas-related Seabed Structures in the Western Irish Sea (IRL-SEA6). Technical Report, Strategic Environmental Assessment SEA6.

Çukur, D., Krastel, S., Schlüter, F.D., Demirbag, E., Imren, C., Niessen, F., Toker, M., PaleoVan-Working Group, 2013a. Sedimentary evolution of Lake Van (Eastern Turkey) reconstructed from high resolution seismic investigations. Int. J. Earth Sci. 102 (2), 571-585. http://dx.doi.org/10.1007/s00531-012-0816-x. 
Çukur, D., Krastel, S., Schmincke, H.U., Sumita, M., Tomonaga, Y., Çagatay, M.N., 2014. Water level changes in Lake Van, Turkey, during the past ca. 600 ka: climatic, volcanic and tectonic controls. J. Paleolimnol. 52, 201-214, http://dx.doi.org/10.1007/s10933-014-9788-0.

Çukur, D., Krastel, S., Tomonaga, Y., Çagatay, M.N., Meydan, A.F., and the PaleoVan Science Team, $2013 \mathrm{~b}$. Seismic evidence of shallow gas from Lake Van, eastern Turkey. Mar. and Pet. Geo. (48) 341-353, http://dx.doi.org/10.1016/j.marpetgeo.2013.08.017.

Davis, A.M., 1992. Shallow gas: an overview. Cont. Shelf Res. 12, 1077-1079.

Davy B. 1992. Seismic reflection profiling on southern Lake Rotorua-evidence for gas-charged lake floor sediments. Geothermics 21, 97-108.

Domżalski, J., Górecki, W., Mazurek, A., Myśko, A., Strzetelski, W., Szamałek, K., (2004), The prospects for petroleum exploration in the eastern sector of Southern Baltic as revealed by sea bottom geochemical survey correlated with seismic data. Przegląd Geologiczny 52 (8/2): 792-799.

Duarte H., Pinheiro L.M., Teixeira F.C. and Monteiro J.H. 2007. High-resolution seismic imaging of gas accumulations and seepage in the sediments of the Ria de Aveiro barrier lagoon (Portugal). Geo-Marine Letters 27, 115-126.

Emeis, K.C., V. Bruchert, B. Currie, R. Endler, T. Ferdelman, A. Kiessling, T. Leipe, K. Noli-Peard, U. Struck, and T. Vogt (2004), Shallow gas in shelf sediments of the Namibian coastal upwelling ecosystem, Cont. Shelf Res. 24, 6, 627-642, doi: 10.1016/j.csr.2004.01.007.

Emery K.O. and Hoggan D. 1958. Gases in marine sediments. AAPG Bulletin 42, 2174-2188. Fleischer, P., T.H. Orsi, M.D. Richardson, and A.L. Anderson (2001), Distribution of free gas in marine sediments: a global overview, Geo-Mar. Lett. 21, 2, 103-122, doi: 10.1007/s003670100072.

Fleischer, P., Orsi, T.H., Richardson, M.D., Anderson, A.L., 2001. Distribution of free gas in marine sediments: a global overview. Geo-Mar. Lett. 21, 103-122.

Garcia-Gil S., Vilas F. and Garcia-Garcia A. 2002. Shallow gas features in incised-valley fills (Ria de Vigo, NW Spain): a case study. Continental Shelf Research 22, 2303-2315.

Gay, A., Lopez, M., Berndt, C., Séranne, M., 2007. Geological controls on focused fluid flow associated with seafloor seeps in the Lower Congo Basin. Marine Geology, 244, 68-92.

Gwang H. Lee, Dae C. Kim, Han J. Ki, Hyeong T. Jou, Young J. Lee (2005): Shallow gas in the central part of the Korea Strait shelf mud off the southeastern coast of Korea. Continental Shelf Research, 25, 20362052.

Hovland, M., 1981a. A classification of pockmarks related features in the Norwegian Trench. Continental Shelf Institute (IKU), publication no. 106, 28 pp. 
Hovland, M., 1981b. Characteristics of pockmarks in the Norwegian Trench. Marine Geology, 39, 103-117.

Hovland, M., 1982. Pockmarks and the Recent geology of the central section of the Norwegian Trench. Mar. Geol., 47, 283-301.

Hovland, M. 1984. Gas-induced erosion features in the North Sea. Earth Surf Proc. and Landforms, 9, 209228.

Hovland, M., 1989. The formation of pockmarks and their potential influence on offshore construction. Quart. J. Engineering Geol., 22, 131-138.

Hovland, M., 1992. The effects of shallow gas in the Skagerrak surficial sediments. Geol. Föreningens i Stockholm Förhandlingar, 114, 235-251.

Hovland, M., 2008. Deep-water coral reefs: Unique Biodiversity hotspots. Praxis Publishing (Springer), Chichester, UK, 278 pp.

Hovland, M., and Judd, A.G., 1988. Seabed Pockmarks and Seepages. Impact on Geology, Biology and the Marine Environment. Graham \& Trotman Ltd., London, 293 pp.

Hage, S., Hubert-Ferrari, A., Lamair, L., Avşar, U., El Ouahabi, M., Van Daele, M., et al. (2017). Flow dynamics at the origin of thin clayey sand lacustrine turbidites: Examples from Lake Hazar, Turkey. Sedimentology, 64(7), 1929-1956.

Hartwig, A., Anka, Z., di Primio, R., 2012. Evidence of a widespread paleo-pockmarked field in the Orange Basin: An indication of an early Eocene massive fluid escape event off-shore South Africa. Marine Geology, 332-334, 222-234.

Hovland M (1981) Characteristics of pockmarks in the Norwegian Trench. Mar Geol 39:103-117.

Hovland, M., A.G. Judd, and R.A. Burke Jr. (1993), The global flux of methane from shallow submarine sediments, Chemosphere 26, 1-4, 559-578, doi: 10.1016/0045-6535(93)90442-8.

Hustoft, S., Bünz, S., Mienert, J., 2010. Three-dimensional seismic analysis of the morphology and spatial distribution of chimneys beneath the Nyegga pockmark field, offshore mid-Norway. Basin Res. 22, 465480. http://dx.doi.org/ 10.1111/j.1365-2117.2010.00486.x.

Jackson, D.R, and Richardson, M., (2007) High-frequency seafloor acoustics. Springer-Verlag, New York.

Jakobsson, M., Bjorck, S., O’Regan, M., Floden, T., Greenwood, S. L., Sward, H., et al. (2014). Major earthquake at the Pleistocene-Holocene transition in Lake Vattern, southern Sweden. Geology, 42(5), 379-382.

Jaśniewicz, D., Klusek, Z., Brodecka-Goluch, A., Bolałek, J., 2019. Acoustic investigations of shallow gas in the southern Baltic Sea (Polish Exclusive Economic Zone): a review. Geo-Marine Letters (2019) 39:1-17, 
https://doi.org/10.1007/s00367-018-0555-5.

Judd A.G. and Hovland M. 2007. Seabed Fluid Flow, the Impact on Geology, Biology and Marine Environment, pp. 475. Cambridge University Press.

Judd AG, Hovland M, Dimitrov LI, Garcia-Gill S, Jukes V (2002) The geological methane budget at continental margins and its influence on climate change. Geofluids 2:109-126.

Judd, A.G., and M. Hovland (1992), The evidence of shallow gas in marine sediments, Cont. Shelf Res. 12, 10, 1081-1096, doi: 10.1016/0278-4343(92) 90070-Z.

Jobe, Z.R., Lowe, D.R., 2009. Pockmarks on the modern seafloor as indicators of submarine Canyon abandonment, offshore equatorial. In: AAPG Search and Discovery Article, Pacific Section Meeting, Ventura, California.

Judd, A.G., and Curzi, P.V., 2002. The rising influence of shallow gas: an introduction to the Bologna Conference on 'Gas in Marine Sediments'. Cont. Shelf Res. 22, 2267-2271.

Kaden, H., Peeters, F., Lorke, A., Kipfer, R., Tomonaga, Y., Karabiyikoglu, M., 2010. Impact of lake level change on deep-water renewal and oxic conditions in deep saline Lake Van, Turkey. Water Resour. Res 46, W11508.

Kipfer, R., Aeschbach-Hertig, W., Baur, H., Hofer, M., Imboden, D.M., Signer, P., 1994. Injection of mantle type helium into Lake Van (Turkey): the clue for quantifying deep water renewal. Earth Planet. Sci. Lett. 125, 357-370.

Kurtman, F., Akkus, M.F., Gedik, A., 1978. The geology and oil potential of Mus-Van region. In: Degens, E.T., Kurtman, F. (Eds.), Geology of Lake Van, 169. M.T.A. Press, Ankara, pp. 124-133.

Kwiecien, O., Stockhecke, M., Pickarski, N., Heumann, G., Litt, T., Sturm, M., Anselmetti, F., Kipfer, R., Haug, G.H., 2014, Dynamics of the last four glacial terminations recorded in Lake Van, Turkey, Quaternary Science Reviews (104) 42-52, http://dx.doi.org/10.1016/j.quascirev.2014.07.001.

Kelley J.T, Dickson S.M, Belknap D.F, Barnhardt W.A, Henderson M (1994) Giant sea-bed pockmarks: evidence for gas escape from Belfast Bay. Mar Geol 22:59-62.

King, L.H., MacLean, B., (1970) Pockmarks on the Scotian Shelf. Geol Soc Am Bull 81: 3141-3148.

Koyama, T., 1953. Measurement and analysis of gases in lake muds. Journal of Earth Sciences (Nagoya University) 1, 107-118.

Kuhlmann, G., Adams, S., Campher, C., Van Der Spuy, D., di Primio, R., Horsfield, B., 2010. Passive margin evolution and its controls on natural gas leakage in the southern Orange Basin, blocks 3/4, offshore South Africa. Marine and Petroleum Geology, 27, 973-992. 
Laier, T., and Jensen, J. B., 2007. Shallow gas depth-contour map of the Skagerrak, western Baltic Sea region. Geo-Mar. Lett. 27, 127-141.

Leroy, S. A., Schwab, M. J., and Costa, P. J. (2010). Seismic influence on the last 1500-year infill history of Lake Sapanca (North Anatolian Fault, NW Turkey). Tectonophysics, 486 (1-4), 15-27.

Lodolo, E., Baradello, L., Darbo, A., Caffau, M., Tassone, A., Lippai, H., Lodolo, A., De Zorzi, G., and Grossi, M., 2012, Occurrence of shallow gas in the easternmost Lago Fagnano (Tierra del Fuego), Near Surface Geophysics (10), 161-169, doi:10.3997/1873-0604.2011040.

Lowe, J.J., and Walker, M.J.C. (1997), Reconstructing Quaternary Environments, Longman Publ., London, $446 \mathrm{pp}$.

Litt, T., Anselmetti, F.S., Cagatay, M.N., Kipfer, R., Krastel, S., Schmincke, H.U., PaleoVan Working Team, 2011. A 500,000 year-long sedimentary archive drilled in Eastern Anatolia (Turkey), The PaleoVan Drilling Project. EOS, 453-164.

Litt, T., Krastel, S., Sturm, M., Kipfer, R., Orcen, S., Heumann, G., Franz, S.O., Ulgen, U.B., Niessen, F., 2009. PALEOVAN, International Continental Scientific Drilling Program (ICDP): site survey results and perspectives. Quat. Sci. Rev. 28 (15-16), 1555-1567.

Litt, T., Pickarski, N., Heumann, G., Stockhecke, M., Tzedakis, P.C., 2014, A 600,000-year long continental pollen record from Lake Van, eastern Anatolia (Turkey), Quaternary Science Reviews, http://dx.doi.org/10.1016/j.quascirev.2014.03.017.

Mathys M., Thiessen O., Theilen F. and Schmidt M. 2005. Seismic characterization of gas-rich near surface sediments in the Arkona Basin, Baltic Sea. Marine Geophysical Research 26, 207-224.

Mazumdar, A., A. Peketi, P. Dewangan, F. Badesab, T. Ramprasad, M.V. Ramana, D.J. Patil, and A. Dayal (2009), Shallow gas charged sediments off the Indian west coast: Genesis and distribution, Mar. Geol. 267, 1-2, 71-85, DOI: 10.1016/j.margeo.2009.09.005.

Missiaen T., Murphy S., Loncke L. and Henriet J.-P. 2002. Very high-resolution seismic mapping of shallow gas in the Belgian coastal zone. Continental Shelf Research 22, 2291-2301.

Naudts, L., De Batist, M., Greinert, J., Artemov, Y., 2009. Geo- and hydro-acoustic manifestations of shallow gas and gas seeps in the Dnepr paleo-delta, northwestern Black Sea. Lead. Edge 28, 1030-1040.

Nelson, H, Tor, D.R, Sandstrom, M.W, Kvenvolden, K.A (1979) Modern biogenic gas-related craters (seafloor_pockmarks_) on the Bering Shelf, Alaska. Geol Soc Am Bull 90: 1144-1152.

Orange D., Garcia-Garcia A., Lorenson T., Nittrouer C., Milligan T., Miserocchi S. et al. 2005. Shallow gas and flood deposition on the Po Delta. Marine Geology 222-223, 159-177. 
Ostanin, I., Anka, Z., di Primio, R., and Bernal, A. (2012) Identification of a large Upper Cretaceous Polygonal Fault network in the Hammerfest Basin: Implications on the reactivation of regional faults and gas leakage dynamics, SW Barents Sea. Marine Geology, 332-334, 109-125. doi:

http://dx.doi.org/10.1016/j.margeo.2012.03.005.

Pickrill, R.A., (1993) Shallow seismic stratigraphy and pockmarks of a hydrothermally influenced lake, Lake Rotoiti, New Zealand. Sedimentology 40:813-828.

Pig-Pib, 2008, Petrobaltic, Kronos, Geos, Geosfera (consortium). Strefy perspektywnczne dla występowania złóż węglowodorów (in Polish). In: Anolik, P., Karczewska, A., (eds.) Badania geochemiczne południowego Bałtyku pod kątem analizy skażeń geogenicznych I poszukiwań naftowych (in Polish). Polish Geological Institute, Warsaw part II.

Pilcher, R. and Argent, J., 2007. Mega-pockmarks and linear pockmark trains on the West African continental margin. Marine Geology, 244, 15-32.

Prior, D.B, and Coleman, J.B., (1984) Submarine slope instability. In: Brunsden D, Prior DB (eds) Slope instability. Wiley, New York, pp 419-455.

Randlett, M.-E., A. Bechtel, M. T. J. van der Meer, F. Peterse, T. Litt, N. Pickarski, O. Kwiecien, M. Stockhecke, B. Wehrli, and C. J. Schubert, 2017, Biomarkers in Lake Van sediments reveal dry conditions in eastern Anatolia during 110.000-10.000 years B.P., Geochem. Geophys. Geosyst., 18, 571-583, doi:10.1002/2016GC006621.

Schroot, B.M., and Schuttenhelm, R.T.E., 2003. Expressions of shallow gas in the Netherlands North Sea. Neth. J. Geosci. 82, 91-105.

Stockhecke, M, Kwiecien, O, Vigliotti, L, Anselmetti, F.S, Beer, J, Cagatay, M.N, Channell, J.E.T, Kipfer, R, Lachner, J, Litt, T, Pickarski, N, Sturm, M., 2014a, Chronostratigraphy of the 600,000 year old continental record of Lake Van (Turkey). Quat Sci Rev. doi:10.1016/j.quascirev.2014.04.008.

Stockhecke M, Sturm M, Brunner I, Schmincke HU, Sumita M, Kipfer R, Cukur D, Kwiecien O, Anselmetti F.S., 2014b, Sedimentary evolution and environmental history of Lake Van (Turkey) over the past 600,000 years. Sedimentology. doi:10.1111/sed.12118.

Sammartini, M., Moernaut, J., Anselmetti, F.S., Hilbe, M., Lindhorst, K., Praet, N., and Strasser, M., 2020, an Atlas of Mass-Transport Deposits in Lakes in Submarine Landslides: Subaqueous Mass Transport Deposits from Outcrops to Seismic Profiles, Geophysical Monograph 246, First Edition. Edited by Kei Ogata, Andrea Festa, and Gian Andrea Pini. 2020 American Geophysical Union. Published 2020 by John Wiley \& Sons, Inc.

Schubel, J.R. (1974), Gas bubbles and the acoustically impenetrable, or turbid, character of some estuarine sediments. In: I.R. Kaplan (ed.), Natural Gases in Marine Sediments, Plenum Press, New York, 
Schüler, F., (1952) Untersuchungen uber die Machtigkeiten von Schlickschichten mit Hilfe des Echographen (In Deutsch). Deutsche Hydrographische Zeitschrift 5:220-231.

Shiki, T., Kumon, F., Inouchi, Y., Kontani, Y., Sakamoto, T., Tateishi, M., et al. (2000). Sedimentary features of the seismo-turbidites, Lake Biwa, Japan. Sedimentary Geology, 135 (1-4), 37-50.

Solheim A, Elverhoi A (1993) Gas-related sea floor craters in the Barents Sea. Geo-Mar Lett 13:235-243.

Solovyeva, M. A., Starovoytov, A. V., Akhmanov, G. G., Khlystov, O. M., Khabuev, A. V., Tokarev, M. Y., \& Chensky, D. A. (2016). The evolution of slump-induced destruction of Kukuy Griva slope (Lake Baikal) revealed on the base of the data of seismic and acoustic surveys. Moscow University Geology Bulletin, $71(6), 416-428$.

Taylor, D.I., 1992. Near shore shallow gas around the U.K. coast. Cont. Shelf Res. 12, 1135-1144.

Toker, M., 2013. Time-dependent analysis of aftershock events and structural impacts on intraplate crustal seismicity of the Van earthquake (Mw 7.1, 23 October 2011), E-Anatolia. Cent. Eur. J. Geosci. 5 (3), 423-434. https://doi.org/10.2478/s13533-012-0141-8.

Toker, M., 2014. Discrete characteristics of the aftershock sequence of the 2011 Van earthquake. J. Asian Earth Sci. 92, 168-186. https://doi.org/10.1016/j.jseaes.2014.06.015.

Toker, M., 2015, Preliminary results of Lake Erçek Seismic Survey (LESS, in: 2015). Project Report in Scientific Research Projects-Coordination Unit, 2015-MiM-B119. Yuzuncu Yil University, Van, Turkey.

Toker, M., 2017. The b-value analysis of aftershocks 170 days after the 23 October 2011 Van earthquake $(\mathrm{Mw}, 7.1)$ of the Lake Van basin, Eastern Anatolia: a new perspective on the seismic radiation and deformation characteristics. In: Zouaghi, T. (Ed.), Earthquakes - Tectonics, Hazard and Risk Mitigation.

Toker, M., Pınar, A., Tur, H., 2017b. Source mechanisms and faulting analysis of the aftershocks in the Lake Erçek area (Eastern Anatolia, Turkey) during the 2011 Van event (Mw 7.1): implications for the regional stress field and ongoing deformation processes. J. Asian Earth Sci. 150, 73-86.

Toker, M., Şahin, Ş. 2019. Crustal Poisson's ratio tomography and velocity modeling across tectonomagmatic lake regions of Eastern Anatolia (Turkey): New geophysical constraints for crustal tectonics, Journal of Geodynamics, 131, 101651, 1-28.

Toker, M., Şengör, A.M.C., 2011. Van Gölü havzasının temel yapısal unsurları, tektonik ve sedimanter evrimi, Doğu Türkiye (Structural elements of Lake Van basin, its tectonic and sedimentary evolution, Eastern Turkey). ITU J. Ser. D: Eng. 10, 119-130. 
Toker, M., Sengör, A.M.C., Demirel-Schluter, F., Demirbağ, E., Çukur, D., Imren, C., Niessen, F., Group, P.-W., 2017a. The structural elements and tectonics of the Lake Van basin (Eastern Anatolia) from multichannel seismic reflection profiles. J. Afr. Earth Sci. 129, 165-178.

Toker, M., and Tur, H., 2018. Structural patterns of the Lake Erçek Basin, eastern Anatolia (Turkey): evidence from single-channel seismic interpretation. Mar Geophys Res. 39: 567-588, https://doi.org/10.1007/s11001-017-9333-4.

Toker, M., 2021. The Structural Coupling to Rupture Complexity of the Aftershock Sequence of the 2011 Earthquakes in Lake Van Area (Eastern Anatolia, Turkey), Journal of Engineering Sciences and Design, 9(1), doi:10.21923/jesd.861520.

Tomonaga, Y., Brennwald, M.S., Kipfer, R., 2011. Spatial distribution and flux of terrigenic He dissolved in the sediment pore water of Lake Van (Turkey). Geochim. Cosmochim. Acta 75 (10), 2848-2864.

Tomonaga, Y., Brennwald, M.S., Livingstone, D.M., , Kwiecien, O., Randlett, M-Ė., Stockhecke, M., Unwin, K., Anselmetti, F.S., Beer, J., Haug, G.H., Schubert, C.J., Sturm, M., and Kipfer, R., 2017. Porewater salinity reveals past lake-level changes in Lake Van, the Earth's largest soda lake. Scientific Reports (7) 313, doi: 10.1038/s41598-017-00371-w.

Toth Zs., Spiess V. and Jensen J. 2014. Seismo-acoustic signatures of shallow free gas in the Bornholm Basin, Baltic Sea. Continental Shelf Research 88, 228-239.

Van Daele, M., Moernaut, J., Doom, L., Boes, E., Fontijn, K., Heirman, K., et al. (2015). A comparison of the sedimentary records of the 1960 and 2010 great Chilean earthquakes in 17 lakes: Implications for quantitative lacustrine palaeoseismology. Sedimentology, 62(5), 1466-1496.

Vardar, D., and Alpar, B., 2016. High-Resolution Seismic Characterization of Shallow Gas Accumulations in the Southern Shelf of Marmara Sea, Turkey, Acta Geophysica, vol. 64, no. 3, June 2016, pp. 589-609, doi: 10.1515/acgeo-2015-0059.

Vardar, D., K. Ozturk, C. Yaltırak, B. Alpar, and H. Tur (2014), Late Pleistocene-Holocene evolution of the southern Marmara shelf and sub-basins: middle strand of the North Anatolian fault, southern Marmara Sea, Turkey, Mar. Geophys. Res. 35, 1, 69-85, doi: 10.1007/s11001-013-9210-8.

Visnovitz, F., Bodnar, T., Toth, Zs., Spiess, V., Kudo, I., Timar, G., and Horvath, F., 2015. Seismic expressions of shallow gas in the lacustrine deposits of Lake Balaton, Hungary. Near Surface Geophysics, 2015, 13 , 433-446, doi:10.3997/1873-0604.2015026.

Vigliotti, L., Channell, J.E.T., Stockhecke, M., 2014, Paleomagnetism of Lake Van sediments: chronology and paleoenvironment since 350 ka, Quaternary Science Reviews (104), 18-29. http://dx.doi.org/10.1016/j.quascirev.2014.09.028. 
Wagner, B., Francke, A., Sulpizio, R., Zanchetta, G., Lindhorst, K., Krastel, S., et al. (2012). Possible earthquake trigger for 6 th century mass wasting deposit at Lake Ohrid (Macedonia/Albania). Climate of the Past, 8(6), 2069-2078.

Wallner, J. (2008). Holozane Landschaftsentwicklung am Lago Budi, Chile $\left(38,9^{\circ} \mathrm{C}\right)$ :

Palaolimnologisch/palaoseismische Untersuchungen an Lagunensedimenten (Doctoral dissertation). Jena, Germany: University of Jena.

Whiticar, M.J. (2002), Diagenetic relationships of methanogenesis, nutrients, acoustic turbidity, pockmarks and freshwater seepages in Eckernforde Bay, Mar. Geol. 182, 1-2, 29-53, DOI: 10.1016/S00253227(01)00227-4.

Wilkens, R.H., Richardson, M.D., (1998), The influence of gas bubbles on sediment acoustic properties: in situ, laboratory, and theoretical results from Eckernförde Bay, Baltic sea. Cont Shelf Res 18(14): 18591892. https://doi.org/10.1016/S0278-4343(98)00061-2.

Wick, L., Lemcke, G., Sturm, M., 2003, Evidence of Late-glacial and Holocene climatic change and human impact in eastern Anatolia: high resolution pollen, charcoal, isotopic and geochemical records from the laminated sediments of Lake Van, Turkey. Holocene 13: 665-675, J. Paleolimnol.

Wood, W., and Ruppel, C., 2000. Seismic and thermal investigations of hydrate bearing sediments on the Blake Ridge Crest: a synthesis of ODP Leg 164 results. In: Proc. Ocean Drill. Progr. Final Rep. 164, pp. 253264.

Yun, J.W, Orange, D.L, Field, M.E., (1999). Subsurface gas offshore of northern California and its link to submarine geomorphology. Mar Geol 154:357-368.

\section{Figures}



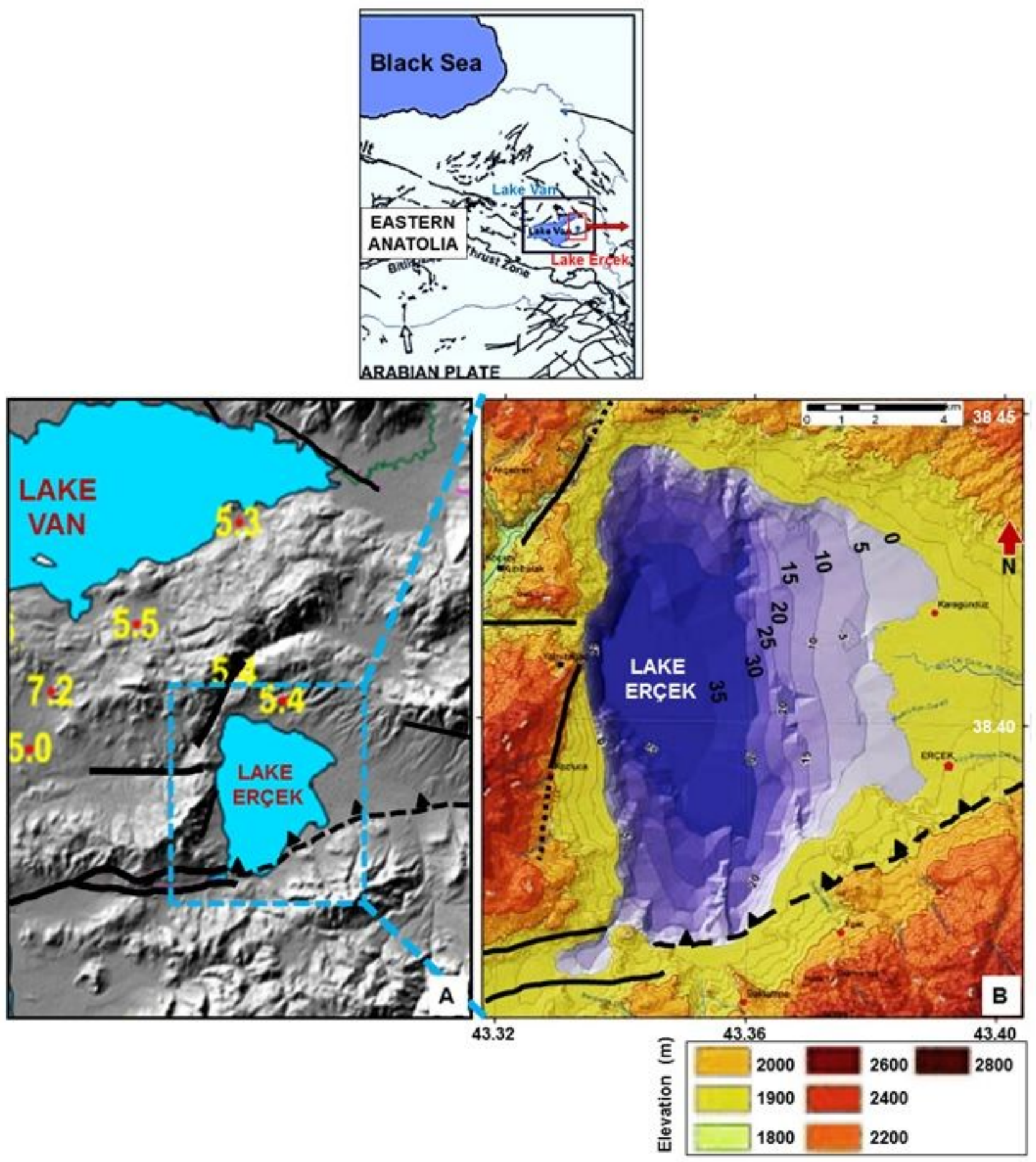

\section{Figure 1}

A. Detailed location of the Lake Erçek region (dashed lines in blue), surrounding topography, main tectonic elements and some major earthquakes (numbers in yellow) (modified after Toker and Tur, 2018). B. The bathymetric map of the Lake Erçek Basin (numbers and contours are depths in meters, Toker and Tur, 2018), surrounding high topography (numbers and contours are elevations in meters), faulting patterns (black lines) and inferred faults (dashed lines) (compiled and modified from Toker and Tur, 2018). Inset map shows Lakes Van (blue) and Erçek (red) regions. 

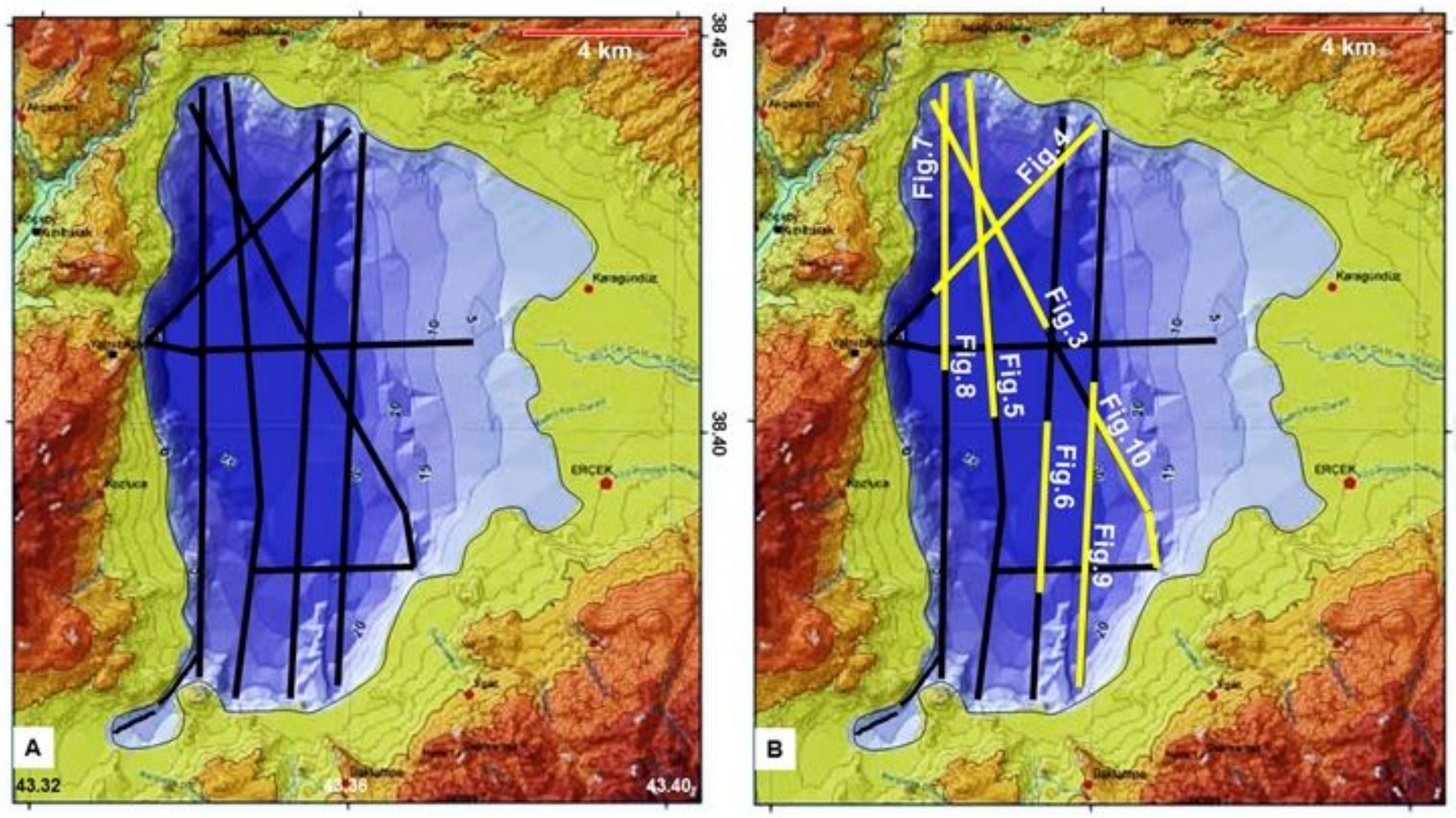

\section{Figure 2}

Profiles of seismic reflection data on bathymetry are shown by thin black lines in (A) (Toker and Tur, 2018). Thick yellow segments marked by figure numbers in (B) indicate the location of seismic profiles shown in Figs. 3-10.

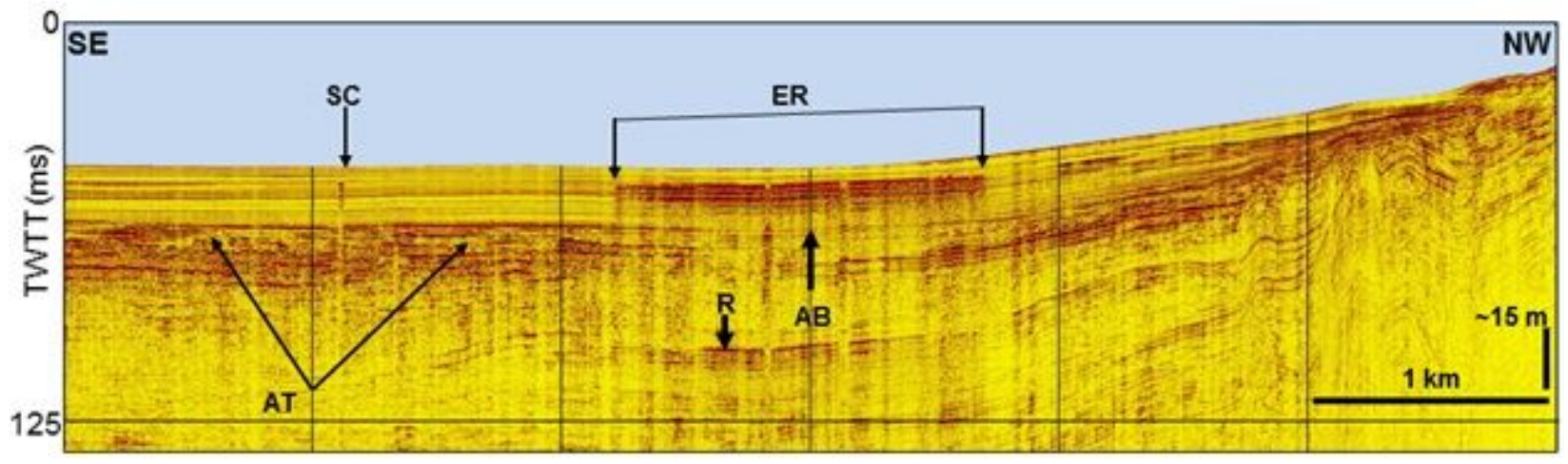

\section{Figure 3}

Seismic profile, showing enhanced reflections, isolated seismic chimney, acoustic blanking and acoustic turbidity observed in the NW-part of the study area (see text for abbreviations). The seismic chimney is associated with acoustic turbidity, while enhanced reflections are accompanied by acoustic blanking. See Fig. $2 \mathrm{~b}$ for the location of seismic profile, (R: reverberation; TWTT: two-way travel time; Horizontal scale gives the count of the shots). 


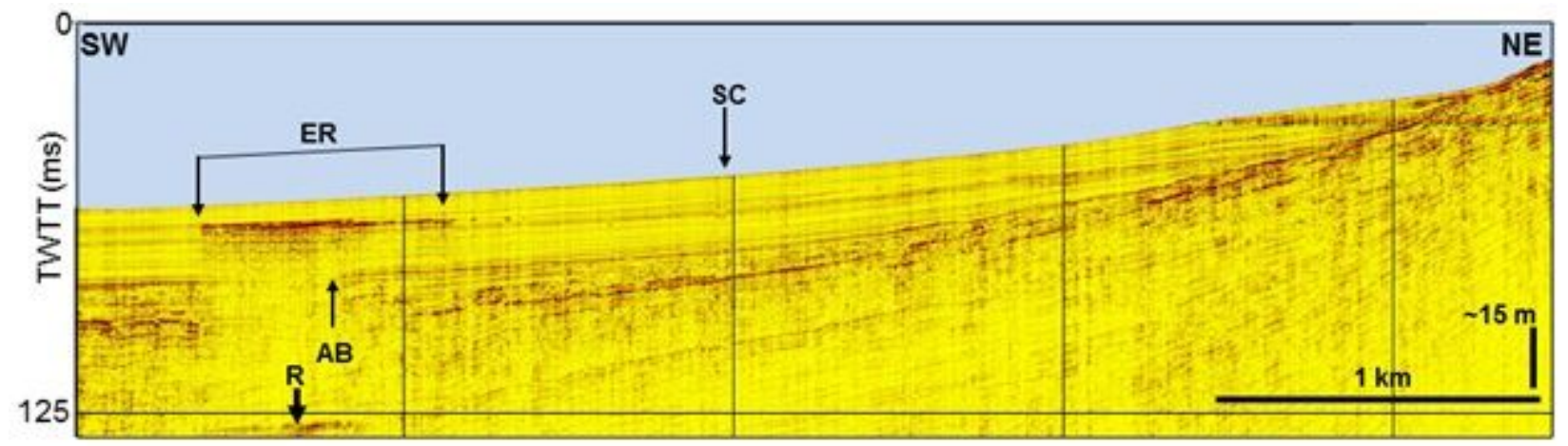

\section{Figure 4}

Seismic profile, showing enhanced reflections, isolated seismic chimney and acoustic blanking observed in the $\mathrm{N}$-part of the study area (see text for abbreviations). Enhanced reflections are accompanied by acoustic blanking. See Fig. $2 b$ for the location of seismic profile, (R: reverberation; TWTT: two-way travel time; Horizontal scale gives the count of the shots).

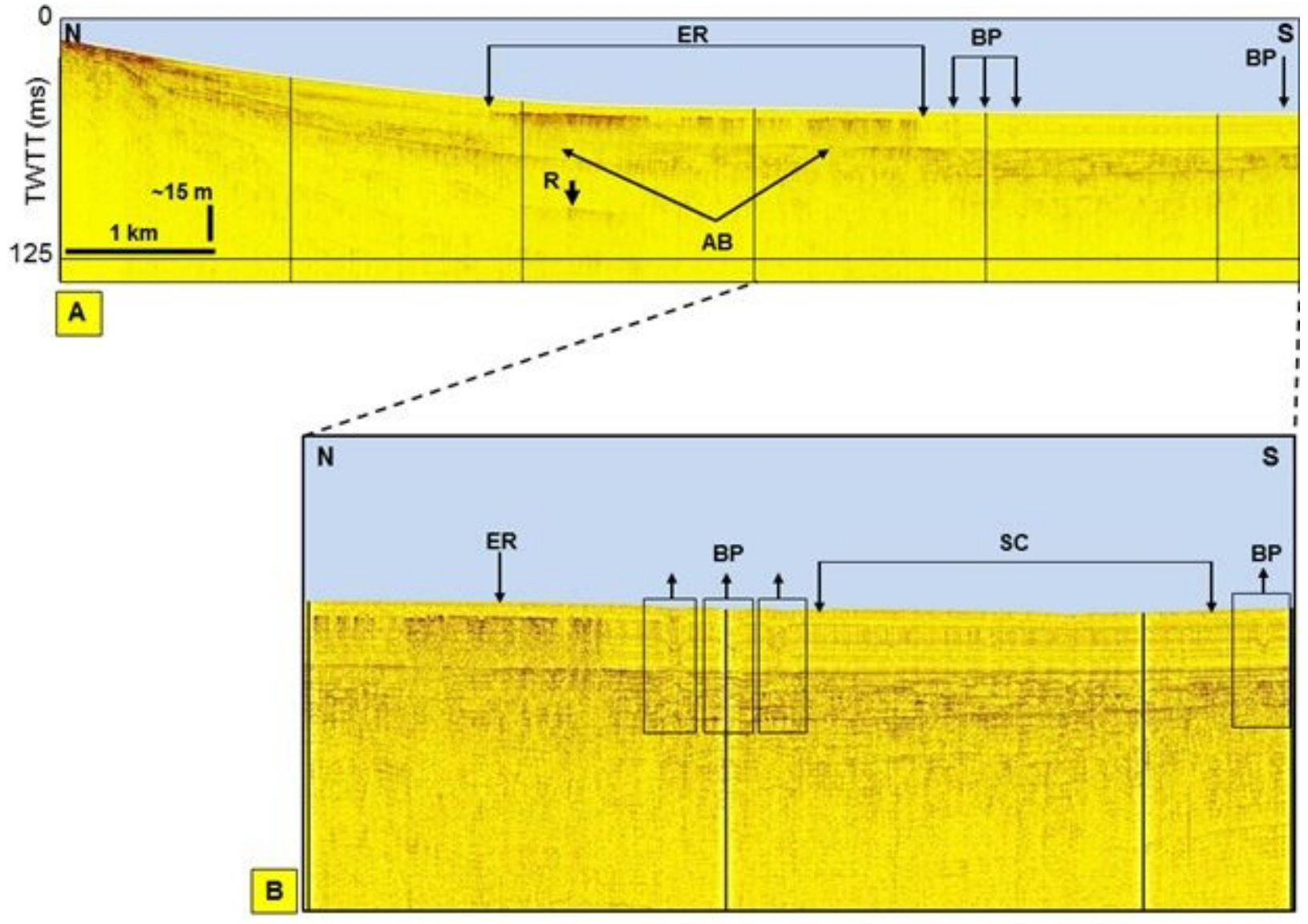

Figure 5

Seismic profile, showing enhanced reflections, seismic chimneys, buried pockmarks and acoustic blanking observed in the NW-part of the study area (see text for abbreviations). Detailed rectangular portion of the seismic section in (A) is shown by dashed black lines in (B). Enhanced reflections in (A) accompanied by acoustic blanking, buried pockmarks and seismic chimneys are notably arranged in line 
in (B). See Fig. 2b for the location of seismic profile, (R: reverberation; TWTT: two-way travel time; Horizontal scale gives the count of the shots).

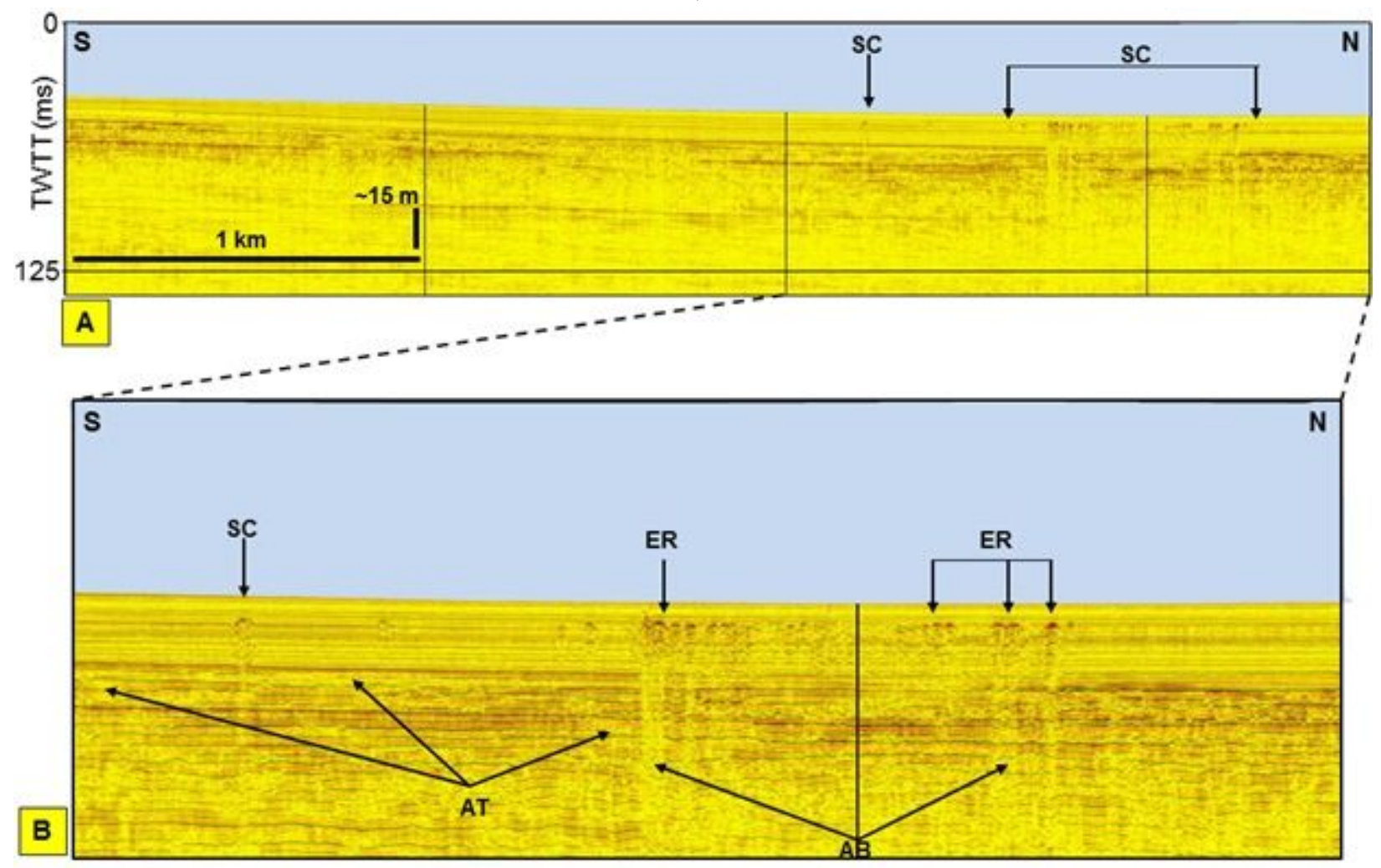

\section{Figure 6}

Seismic profile, showing grouped and isolated seismic chimneys, enhanced reflections, acoustic blanking and acoustic turbidity observed in the S-part of the study area (see text for abbreviations). Detailed rectangular portion of the seismic section in (A) is shown by dashed black lines in (B). Seismic chimneys in (A) are associated with smaller enhanced reflections in (B) and are accompanied by acoustic blanking and acoustic turbidity. See Fig. 2b for the location of seismic profile, (TWTT: two-way travel time; Horizontal scale gives the count of the shots). 


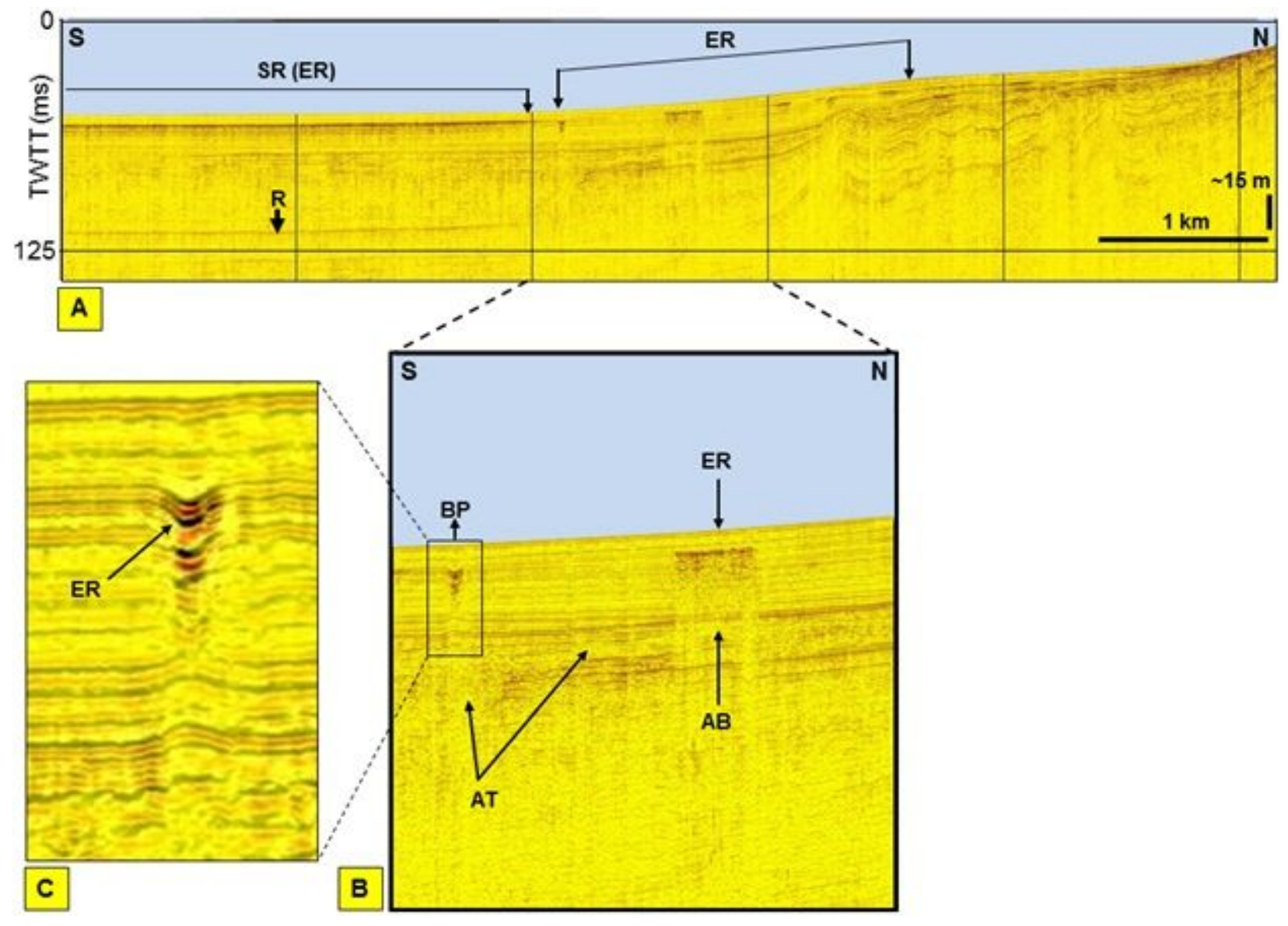

Figure 7

Seismic profile, showing strong reflector and enhanced reflections observed in the NW-part of the study area (see text for abbreviations). Detailed rectangular portions of the seismic section in (A) are shown by dashed thick lines in black in (B) and dashed thin lines in black in (C). Enhanced reflections in (B) are accompanied by acoustic blanking, while buried pockmark in $(B)$ associated with enhanced reflection in (C) is accompanied by acoustic turbidity in (B). See Fig. $2 b$ for the location of seismic profile, (R: reverberation; TWTT: two-way travel time; Horizontal scale gives the count of the shots).

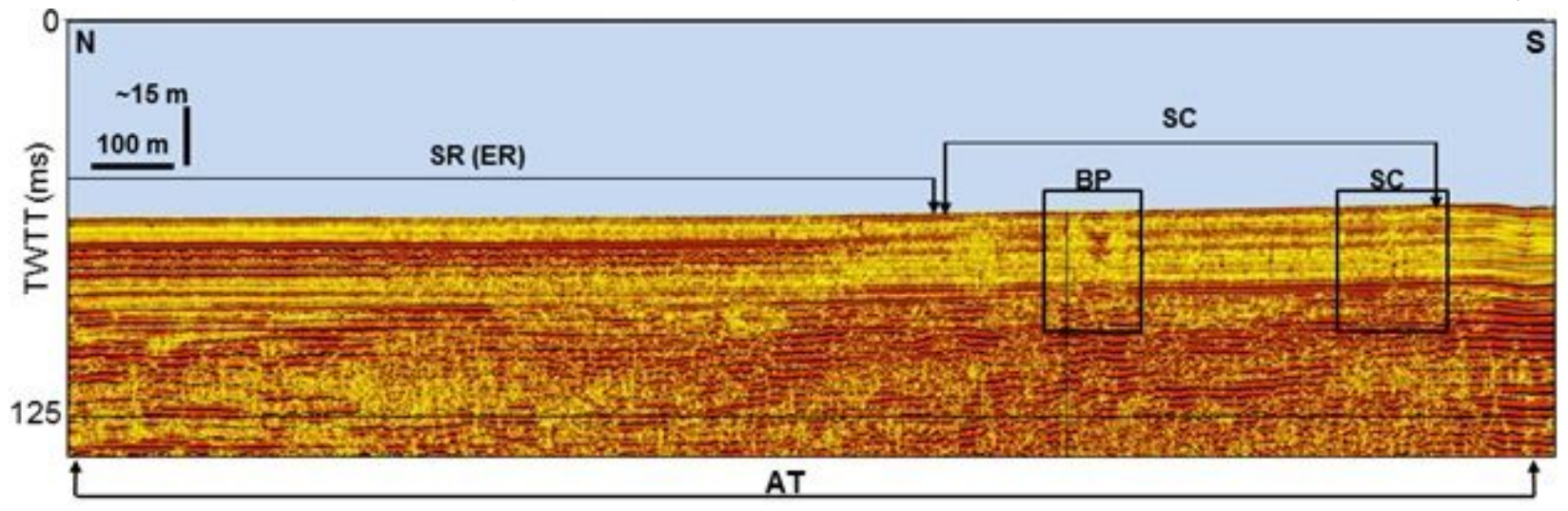

Figure 8 
Seismic profile, showing strong reflector, seismic chimneys, and buried pockmark associated with a prominent zone of acoustic turbidity, observed in the W-part of the study area (see text for abbreviations). Buried pockmark and seismic chimney are sampled in black boxes. See Fig. $2 b$ for the location of seismic profile, (TWTT: two-way travel time; Horizontal scale gives the count of the shots).

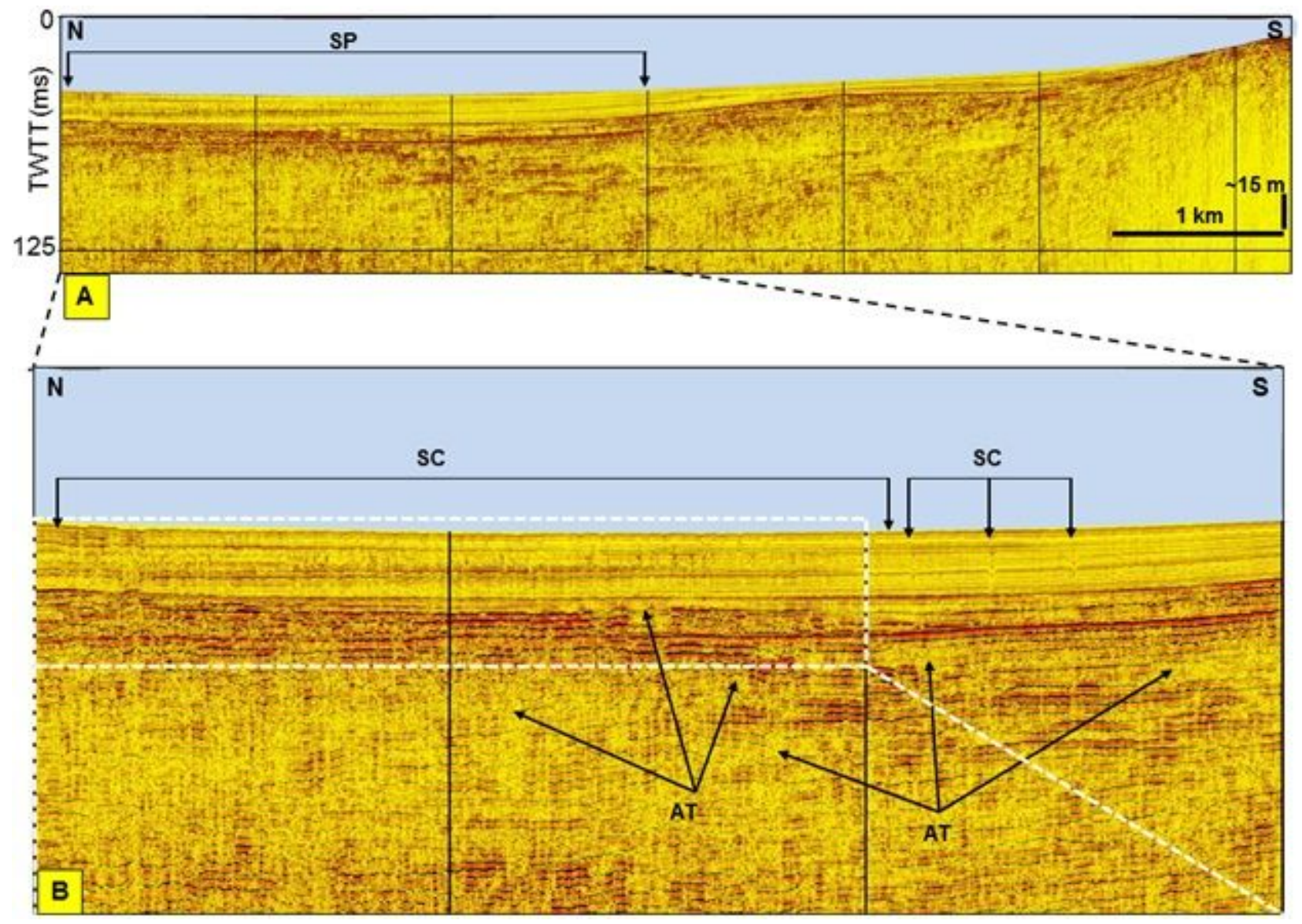

\section{Figure 9}

Seismic profile, showing surface pockmarks and seismic chimneys observed in the SE-part of the study area (see text for abbreviations). Detailed rectangular portions of the seismic section in (A) are shown by dashed black lines in (B) and dashed white lines in (C). Surface pockmarks in (A) are accompanied by seismic chimneys in (B) and are associated with acoustic turbidity in (B). A typical example of a surface pockmark produced by a seismic chimney is sampled in (C). See Fig. $2 b$ for the location of seismic profile, (TWTT: two-way travel time; Horizontal scale gives the count of the shots). 

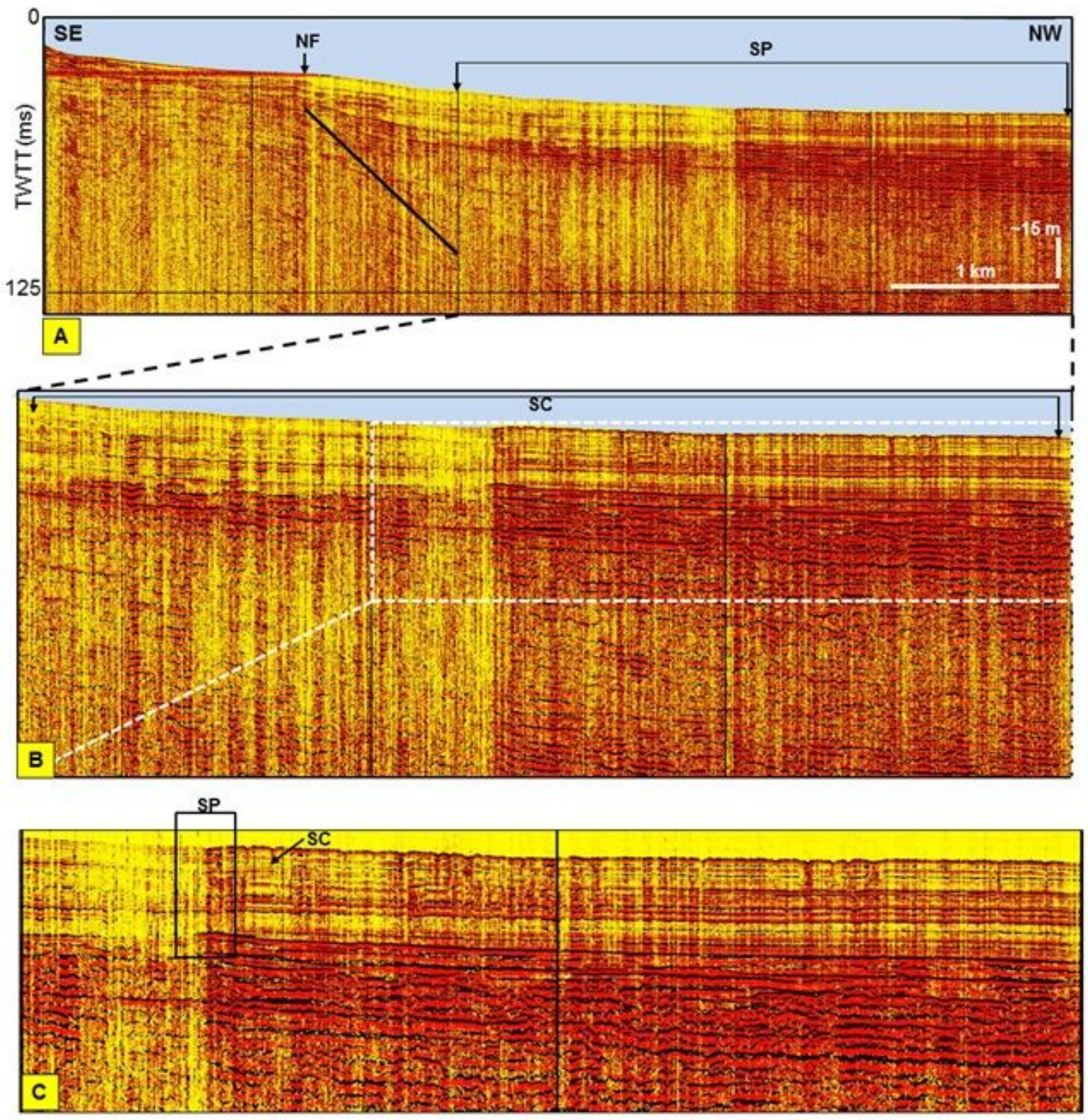

\section{Figure 10}

Seismic profile, showing surface pockmarks and seismic chimneys observed in the SE-part of the study area (see text for abbreviations). Detailed rectangular portions of the seismic section in (A) are shown by dashed black lines in (B) and dashed white lines in (C). A typical example of one of the surface pockmarks in (A), accompanied by seismic chimneys in (B), is sampled in (C). See Fig. $2 b$ for the location of seismic profile, (NF: normal fault; TWTT: two-way travel time; Horizontal scale gives the count of the shots). 


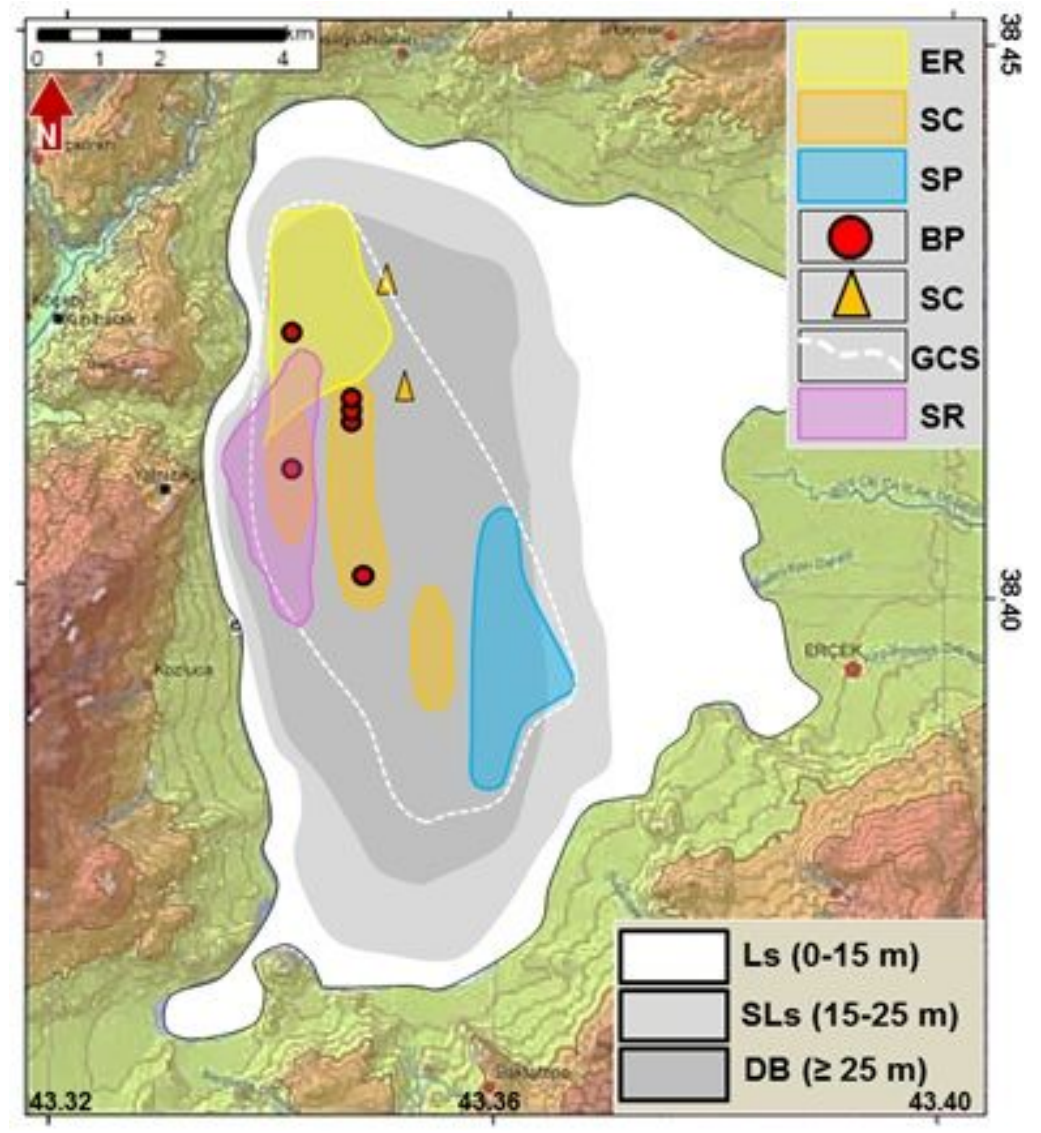

\section{Figure 11}

Distributional patterns of shallow gas anomalies of the Lake Erçek basin correlated with basinal morphotopography (map modified from Toker and Tur, 2018), including lacustrine shelf (Ls), sub-lacustrine slope (SLs) and deep basin (DB). The basinal pattern of gas anomalies correlates well with the water depth $\geq$ $25 \mathrm{~m}$ (DB) (see text for abbreviations). Surface pockmarks are only observed in the SE-part of the basin, where seismic chimneys are also seen and buried pockmarks detected are diffused in a few locations toward the NW. Seismic chimneys are densely observable in most of the surveyed area from SE (surface pockmark area) to NW (enhanced reflection area) and several seismic chimneys (triangles in orange) are diffusely isolated in a few locations toward the NW. Enhanced reflections dominantly clustered in the NWcorner of the basin are associated with the strong reflector, only identified in the W-end of the basin, where some chimneys and buried pockmark are also evident. Gas-charged sediments (GCS) associated with acoustic gas masking are distributed along-strike in a SE to NW pattern. 


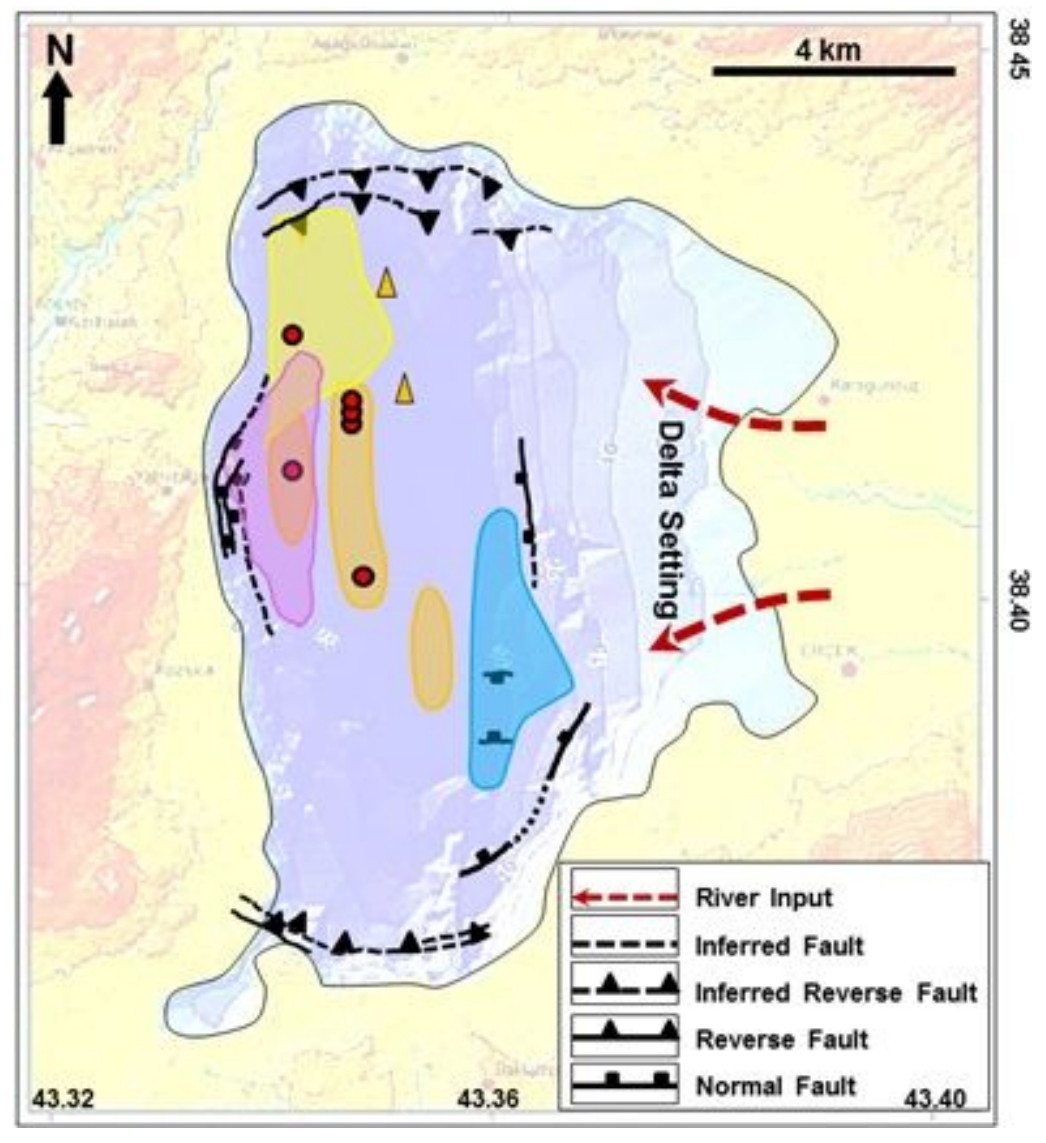

Figure 12

A simplified map of the structural deformation and faulting patterns of the lake (map modified from Toker and Tur, 2018), superimposed on the distributional patterns of the shallow gas shown in Fig. 11 and the lake bathymetry shown in Fig. 1b. Note the fault-controlled distributional patterns of the shallow gas, compatible with bathymetry. 